Portland State University

PDXScholar

6-9-1976

\title{
The Addition of SF5Br to Unsaturated Systems
}

Qui-Chee Wendy Wang

Portland State University

Follow this and additional works at: https://pdxscholar.library.pdx.edu/open_access_etds

Part of the Chemistry Commons

Let us know how access to this document benefits you.

Recommended Citation

Wang, Qui-Chee Wendy, "The Addition of SF5Br to Unsaturated Systems" (1976). Dissertations and Theses. Paper 2552.

https://doi.org/10.15760/etd.2549

This Thesis is brought to you for free and open access. It has been accepted for inclusion in Dissertations and Theses by an authorized administrator of PDXScholar. Please contact us if we can make this document more accessible: pdxscholar@pdx.edu. 
AN ABSTRACT OF THE THESIS OF Qui-Chee Wendy Wang for the Master of Science in Chemistry presented June 9, 1976.

Title: The Addition of $\mathrm{SF}_{5} \mathrm{Br}$ to Unsaturated Systems APPROVED BY MEMBERS OF THE THESIS COMMITTEE:
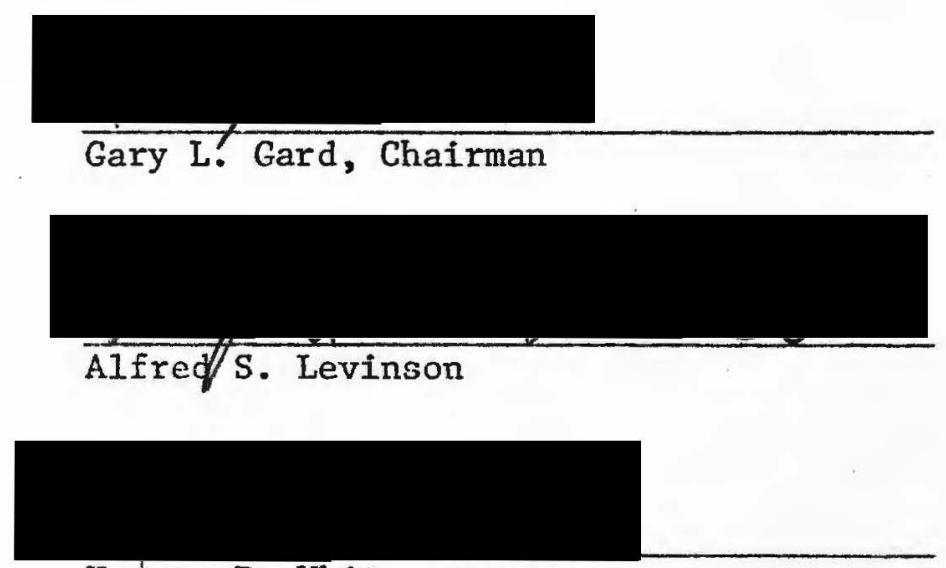

Horace $\mathrm{F}$. White

Addition reactions of pentafluorosulfur bromide with unsaturated substrates were studied and four new compounds containing the pentafluorosulfur group have been prepared.

The mechanism for these reactions seems to involve a radical addition pathway. In reaction with $\mathrm{CH}_{2}=\mathrm{CFC1}, \mathrm{CF}_{3} \mathrm{C} \equiv \mathrm{CH}$ and $\mathrm{CH}_{3} \mathrm{C} \equiv \mathrm{CH}$ the $\mathrm{SF}_{5}$. radical attacks the carbon atoms carrying the most hydrogens. The reaction with $\mathrm{CF}_{2}=\mathrm{CHCl}$ is interesting, as by analogy with other fluoroolefins, the $\mathrm{SF}_{5}$ primary attack should occur at the CHCl group, however, $\mathrm{SF}_{5} \mathrm{CF}_{2} \mathrm{CHClBr}$ was found as the only product for this reaction. The reaction of $\mathrm{SF}_{5} \mathrm{Br}$ with $\mathrm{CF}_{3} \mathrm{C} \equiv \mathrm{CH}$ produced two isomers but with $\mathrm{CH}_{3} \mathrm{C} \equiv \mathrm{CH}$ only one isomer was formed. 
Analytical data, infrared, nmr and mass spectra are presented supporting the proposed structures for these new compounds. 
THE ADDITION OF $\mathrm{SF}_{5}{ }^{\mathrm{Br}}$ TO UNSATURATED SYSTEMS

by

QUI-CHEE WENDY WANG

A thesis submitted in partial fulfillment of the requirements for the degree of

\author{
MASTER OF SCIENCE \\ in \\ CHEMISTRY
}

Portland State University

1976 
TO THE OFFICE OF GRADUATE STUDIES AND RESEARCH:

The members of the Committee approve the thesis of Qui-Chee Wendy Wang presented June 9, 1976.

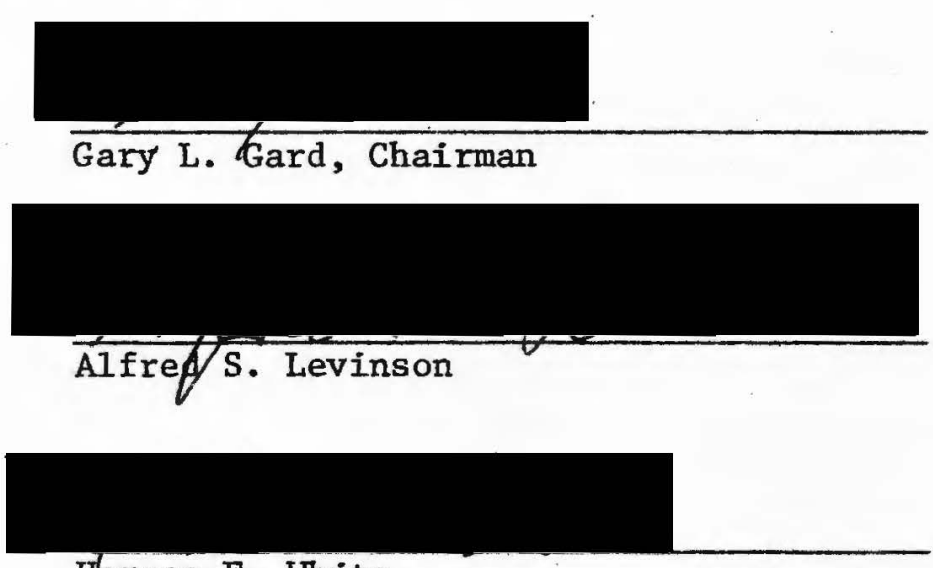

Hbrace F. White

APPROVED:

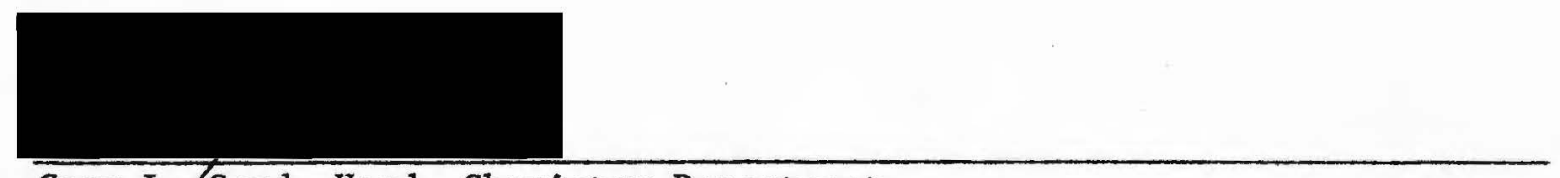

Gary L. Gard, Head, Chemistry Department

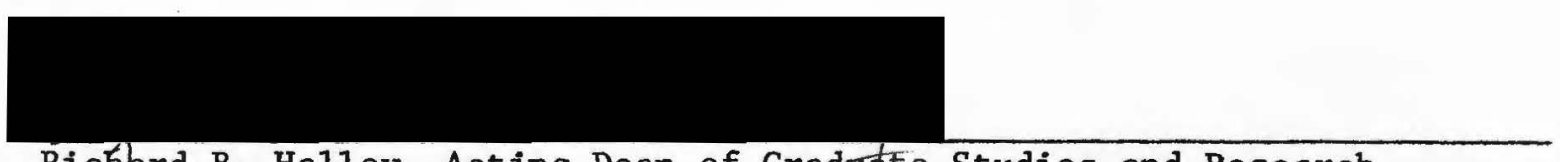

Richlard B. Halley, Acting Dean of Gradudte Studies and Research 


\section{ACKNOWLEDGMENTS}

The author wishes to thank Dr. Gary L. Gard for his patience, guidance and help in this work; to Dr. Alfred S. Levinson for his interest and helpful discussions; to Dr. Horace F. White for his help in interpreting the $\mathrm{nmr}$ spectra; to $\mathrm{Mr}$. W. Anderson of the oregon Graduate Center for obtaining the mass spectra. 
TABLE OF CONTENTS

Page

ACKNOWLEDGMENTS . . . . . . . . . . . . . . . . . . i1i

LIST OF TABLES . . . . . . . . . . . . . . . . . . v v

LIST OF FIGURES . . . . . . . . . . . . . . . . . . vii

CHAPTER

I INTRODUCTION . . . . . . . . . . . . . . 1

II EXPERIMENTAL METHODS . . . . . . . . . 15

III SYNTHESIS OF NEW ADDUCTS OF SF5 $5^{B r}$ REACTION WITH 20

FLUOROOLEFINS AND ACETYLENES . . . . . . . . 20

BIBLIOGRAPHY . . . . . . . . . . . . . . . . . 59 
LIST OF TABLES

TABLE

PAGE

I $\quad \mathrm{SF}_{5} \mathrm{Br}$ and Fluoroolefin Adducts . . . . . . . . 2

II Infrared Spectra Data for $\mathrm{SF}_{5} \mathrm{Br}$ and Fluoroolefin Adducts............. 3

III Gas Chromatography Data for $\mathrm{SF}_{5} \mathrm{Br}$ and Fluoroolefin Adducts .................. 3

IV NMR Spectra Data for $\mathrm{SF}_{5} \mathrm{Br}$ and Fluoroolefin Adducts $\quad 4$

$\mathrm{V} \quad \mathrm{SF}_{5} \mathrm{Cl}$ Adducts with olefins . . . . . . . . . 6

VI $\mathrm{SF}_{5}$ Olefins ................. 7

VII Derivatives of $\mathrm{SF}_{5}$ Compounds . . . . . . . . . 7

VIII Reactions of Arylsulfur Pentafluorides . . . . . . . 11

IX Reaction of $\mathrm{S}_{2} \mathrm{~F}_{10}$ with Olefins......... 12

X Gas Chromatography Data for $\mathrm{SF}_{5} \mathrm{Br}$ Adducts . . . . . 24

XI Elemental Analysis for $\mathrm{SF}_{5} \mathrm{Br}$ Adducts . . . . . . . 24

XII Physical Properties of the Adducts . . . . . . . 25

XII Infrared Absorption Bands for Saturated Adducts . . . 27

XIV Infrared Absorption Bands for Unsaturated Adducts . . 28

$\mathrm{XV}$ Mass Spectra for $\mathrm{SF}_{5} \mathrm{CH}_{2} \mathrm{CFC1Br}$. . . . . . . . 30

XVI Mass Spectra for $\mathrm{SF}_{5} \mathrm{CF}_{2} \mathrm{CHClBr}$. . . . . . . . 31

XVII Mass Spectra for $\mathrm{SF}_{5} \mathrm{CH}=\mathrm{C}\left(\mathrm{CH}_{3}\right) \mathrm{Br}$. . . . . . . 33

XVIII Mass Spectra for $\mathrm{SF}_{5} \mathrm{CH}=\mathrm{C}\left(\mathrm{CF}_{3}\right) \mathrm{Br}$. . . . . . . . 34

XIX Mass Spectra for $\mathrm{SF}_{5} \mathrm{CH}=\mathrm{C}\left(\mathrm{CF}_{3}\right) \mathrm{Br}$, First G.C. Isomer . . 36

XX Mass Spectra for $\mathrm{SF}_{5} \mathrm{CH}=\left(\mathrm{CF}_{3}\right) \mathrm{Br}$, Second G.C. Isomer . . 38 
XXI Mass Spectra for $\mathrm{SF}_{5} \mathrm{CH}=\mathrm{CH}_{2}$. . . . . . . . . 40

XXII NMR Data for New $\mathrm{SF}_{5} \mathrm{Br}$ Adducts .......... 42 


\section{LIST OF FIGURES}

FIGURE

PAGE

I Glass Vacuum Manifold . . . . . . . . . . 16

II Infrared Spectrum for $\mathrm{SF}_{5} \mathrm{CF}_{2} \mathrm{CHClBr}$. . . . . . 49

III Infrared Spectrum for $\mathrm{SF}_{5} \mathrm{CH}_{2} \mathrm{CFClBr}$. . . . . . 50

IV Infrared Spectrum for $\mathrm{SF}_{5} \mathrm{CH}=\mathrm{C}\left(\mathrm{CH}_{3}\right) \mathrm{Br} \ldots . . . . \quad 51$

V Infrared Spectrum for $\mathrm{SF}_{5} \mathrm{CH}=\mathrm{C}\left(\mathrm{CF}_{3}\right) \mathrm{Br}$ Mixture . • 52

VI Infrared Spectrum for $\mathrm{SF}_{5} \mathrm{CH}=\mathrm{C}\left(\mathrm{CF}_{3}\right) \mathrm{Br}-$ First G.C. Fraction .............. 53

VII Infrared Spectrum for $\mathrm{SF}_{5} \mathrm{CH}=\mathrm{C}\left(\mathrm{CF}_{3}\right) \mathrm{Br}$ - Second G.C. Fraction ............ . . 54

VIII NMR Proton Spectrum for $\mathrm{SF}_{5} \mathrm{CF}_{2} \mathrm{CHClBr}$. . . . . 55

IX NMR Proton Spectrum for $\mathrm{SF}_{5} \mathrm{CH}_{2} \mathrm{CFBrCl}$. . . . . . 56

X NMR Proton Spectrum for $\mathrm{SF}_{5} \mathrm{CH}=\mathrm{C}\left(\mathrm{CH}_{3}\right) \mathrm{Br}$. . . . 57

XI NMR Proton Spectrum for $\mathrm{SF}_{5} \mathrm{CH}=\mathrm{C}\left(\mathrm{CF}_{3}\right) \mathrm{Br}$ Mixture . . 58 


\section{CHAPTER I}

\section{INTRODUCTION}

\section{The Addition of $\mathrm{SF}_{5} \mathrm{Br}$ to Unsaturated Systems}

Pentafluorosulfur bromide $\left(\mathrm{SF}_{5} \mathrm{Br}\right)$ was first prepared by C. Merrill (1962) by reacting $\mathrm{SF}_{4}$ with $\mathrm{Br}_{2}$ and $\mathrm{BrF}_{5}$ at $100^{\circ} \mathrm{C}$ under pressure (1). Later (1965), B. Cohen and A. MacDiarmid prepared $\mathrm{SF}_{5} \mathrm{Br}$ by reacting $\mathrm{S}_{2} \mathrm{~F}_{10}$ with $\mathrm{Br}_{2}$ at $138^{\circ}$ (2). $\mathrm{SF}_{5} \mathrm{Br}$ boils at $3.1^{\circ}$ at one atmosphere and melts at $-78.8^{\circ}$ to $-78.4^{\circ}$. Its density is $2.098 \mathrm{~g} / \mathrm{cc}$ at $-20.1^{\circ}$ (1). Strong S-F infrared absorption bands are found for $S F{ }_{5} \mathrm{Br}$ at 11.22 , 11.80 and $14.49 \mu(3)$. In the liquid state $\mathrm{SF}_{5} \mathrm{Br}$ has a faintly yellow color. It decomposes above $150^{\circ}$ and is easily hudrolyzed at room temperature (1) according to the following equations:

$$
\begin{aligned}
& 2 \mathrm{SF}_{5} \mathrm{Br} \stackrel{>150^{\circ}}{\longrightarrow} \mathrm{SF}_{6}+\mathrm{SF}_{4}+\mathrm{Br}_{2} \\
& \mathrm{SF}_{5} \mathrm{Br}+4 \mathrm{H}_{2} \mathrm{O} \longrightarrow \mathrm{SO}_{4}=+5 \mathrm{~F}^{-}+\mathrm{Br}^{-}+8 \mathrm{H}^{+}
\end{aligned}
$$

Pentafluorosulfur bromide is a particularly valuable intermediate for the incorporation of $\mathrm{SF}_{5}$ groups into molecules (4). A. Berry and W. Fox unsuccessfully tried to generate the corresponding $\mathbf{S F}_{5}-\mathbf{s i l i c o n}$ derivatives via reactions of pentafluorosulfur bromide with appropriaately stubstituted silanes (5). However, it is known that $\mathrm{SF}_{5} \mathrm{Br}$ adds to fluoroolefins to form $\mathrm{SF}_{5}$-carbon derivatives readily (4). Results of this work are summarized in Tables I, II, III, and IV. The authors concluded that $\mathrm{SF}_{5} \mathrm{Br}$ should be a useful reagent for introducing $\mathrm{SF}_{5}$ 
groups into carbon compounds. It added more readily and directly than either $\mathrm{SF}_{5} \mathrm{Cl}$ or $\mathrm{S}_{2} \mathrm{~F}_{10}$ and like $\mathrm{SF}_{5} \mathrm{Cl}$ the $\mathrm{SF}_{5}$ group bonds to the carbon of the fluoroolefins carrying the most hydrogens.

Dehydrobromination of the adducts in Table I yield the corresponding $\mathrm{SF}_{5}$ containing olefins (4).

More recent work by $W$. Fox and A. Berry (5) showed that $\mathrm{SF}_{5} \mathrm{Br}$ will add to the olefinic double bonds of several vinyl silanes as follows:

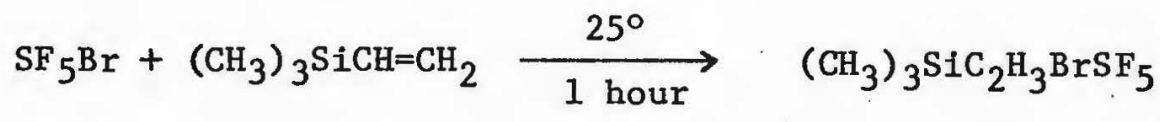

$$
\begin{aligned}
& \mathrm{SF}_{5} \mathrm{Br}+\mathrm{Cl}_{3} \mathrm{SiCH}=\mathrm{CH}_{2} \underset{3 \text { hours }}{\stackrel{0^{\circ}}{\longrightarrow}} \mathrm{Cl}_{3} \mathrm{SiC}_{2} \mathrm{H}_{3} \mathrm{BrSF}_{5}
\end{aligned}
$$

Also, W. Fox and A. Berry (6) reported that the addition of $\mathrm{SF}_{5} \mathrm{Br}$ to pentafluorosulfur ethane $\left(\mathrm{SF}_{5} \mathrm{CH}=\mathrm{CH}_{2}\right)$ produced a bis (pentafluorosulfur) ethane bromide:

$$
\mathrm{SF}_{5} \mathrm{Br}+\mathrm{SF}_{5} \mathrm{CH}=\mathrm{CH}_{2} \longrightarrow \quad\left(\mathrm{SF}_{5}\right)_{2} \mathrm{C}_{2} \mathrm{H}_{3} \mathrm{Br}
$$

Surprisingly, more highly halogenated pentafluorosulfur ethylenes $\left(\mathrm{SF}_{5} \mathrm{CH}=\mathrm{CHF}, \mathrm{SF}_{5} \mathrm{CH}=\mathrm{CF}_{2}, \mathrm{SF}_{5} \mathrm{CF}=\mathrm{CFH}, \mathrm{SF}_{5} \mathrm{CF}=\mathrm{CF}_{2}\right)$ did not undergo $\mathrm{SF}_{5} \mathrm{Br}$ addition to a measurable extent even under more stringent conditions(6).

TABLE I

$\mathrm{SF}_{5} \mathrm{Br}$ and Fluoroolefin Adduct

$\begin{array}{llll}\text { Reactants } & \text { Reaction Conds. } & \left.\text { B.P. }{ }^{\circ} \mathrm{C}\right) & \text { Adducts } \\ \mathrm{SF}_{5} \mathrm{Br}+\mathrm{CH}_{2}=\mathrm{CHF} & 24 \text { hours R.T. } & 99 \cdot 5-100.5 & \mathrm{SF}_{5} \mathrm{CH}_{2} \mathrm{CHFBr} \\ \mathrm{SF}_{5} \mathrm{Br}+\mathrm{CH}_{2}=\mathrm{CF}_{2} & 24 \text { hours R.T. } & 86-87 & \mathrm{SF}_{5} \mathrm{CH}_{2} \mathrm{CF}_{2} \mathrm{Br} \\ \mathrm{SF}_{5} \mathrm{Br}+\mathrm{CHF}=\mathrm{CF}_{2} & 24 \text { hours R.T. } & 74-75 & \mathrm{SF}_{5} \mathrm{CHFCF}_{2} \mathrm{Br} \\ \mathrm{SF}_{5} \mathrm{Br}+\mathrm{CFCl}=\mathrm{CF}_{2} & 24 \text { hours R.T. } & 94-95 & \mathrm{SF}_{5} \mathrm{C}_{2} \mathrm{~F}_{3} \mathrm{C} 1 \mathrm{Br}\end{array}$


TABLE II

INFRARED SPECTRA DATA FOR $\mathrm{SF}_{5} \mathrm{Br}$ AND FLUOROOLEFIN ADDUCTS

$$
\mathrm{Cm}^{-1 *}
$$

$$
\begin{aligned}
& \mathrm{SF}_{5} \mathrm{CH}_{2} \mathrm{CHFBr} \quad 1416 \text { (w),* } 1364 \text { (w), } 1307 \text { (w), } 1196 \text { (w), } 1086 \text { (s), } \\
& 1042 \text { (s), } 900 \text { (vs), } 874 \text { (vs), } 847 \text { (vs), } 751 \text { (w), } \\
& 681 \text { (w) } \\
& \mathrm{SF}_{5} \mathrm{CH}_{2} \mathrm{CF}_{2} \mathrm{Br} \quad 1416 \text { (w), } 1323 \text { (w), } 1274 \text { (w), } 1224 \text { (m), } 1189 \text { (w), } \\
& 1124 \text { (s), } 1047 \text { (m), } 955 \text { (vs), } 914 \text { (m), } 891 \text { (vs), } \\
& 873 \text { (vs), } 855 \text { (vs), } 797 \text { (m), } 741 \text { (w), } 694 \text { (w) } \\
& \mathrm{SF}_{5} \mathrm{CHFCF}_{2} \mathrm{Br} \quad 1324 \text { (w), } 1295 \text { (w), } 1232 \text { (s), } 1161 \text { (vs), } 1060 \text { (m), } \\
& 983 \text { (vs), } 968 \text { (s), } 883 \text { (vs), } 808 \text { (m), } 775 \text { (m), } \\
& 758 \text { (w), } 706 \text { (s) } \\
& \mathrm{SF}_{5} \mathrm{C}_{2} \mathrm{~F}_{3} \mathrm{C} 1 \mathrm{Br} \quad 1214 \text { (s), } 1175 \text { (w), } 1117 \text { (s), } 1055 \text { (w), } 1020 \text { (w), } \\
& 936 \text { (vs), } 894 \text { (vs), } 854 \text { (m), } 816 \text { (m), } 760 \text { (m), } \\
& 724(\mathrm{~s}), 685(\mathrm{~m}) \\
& *_{\mathrm{W}}=\text { weak; } \mathrm{m}=\text { medium; } \mathrm{s}=\text { strong; } \mathrm{vs}=\text { very strong }
\end{aligned}
$$

\section{TABLE III}

GAS CHROMATOGRAPHY DATA* FOR $\mathrm{SF}_{5} \mathrm{Br}^{\mathrm{Br}}$ AND FLUOROOLEFIN ADDUCTS

Compound

$\mathrm{SF}_{5} \mathrm{CH}_{2} \mathrm{CHFBr}$

$\mathrm{SF}_{5} \mathrm{CH}_{2} \mathrm{CF}_{2} \mathrm{Br}$

$\mathrm{SF}_{5} \mathrm{CHFCF}_{2} \mathrm{Br}$

$\mathrm{SF}_{5} \mathrm{C}_{2} \mathrm{P}_{3} \mathrm{ClBr}$

$\mathrm{CCl}_{4}$

Retention Time (min.)

35

15

5.6

3.8

7.5
*The column temperature was $59+1^{\circ}$. Helium flow rate was $2.5 \mathrm{ml} / \mathrm{sec}$. 


\section{TABLE IV}

NMR SPECTRA DATA FOR $\mathrm{SF}_{5}$ Br AND FLUOROOLEFIN ADDUCTS

Proposed Structure

- Skeletal Atom Number

12

3

$\mathrm{SF}_{5} \quad \mathrm{CH}_{2} \quad \mathrm{CHFBr}$

$\mathrm{SF}_{5} \quad \mathrm{CH}_{2} \quad \mathrm{CF}_{2} \mathrm{Br}$

$\mathrm{SF}_{5} \quad \mathrm{CHF} \quad \mathrm{CF}_{2} \mathrm{Br}$

$\mathrm{SF}_{5} \mathrm{C}_{2} \mathrm{~F}_{3} \mathrm{C} 1 \mathrm{Br}+$

Chemical Shifts, Band Centers*

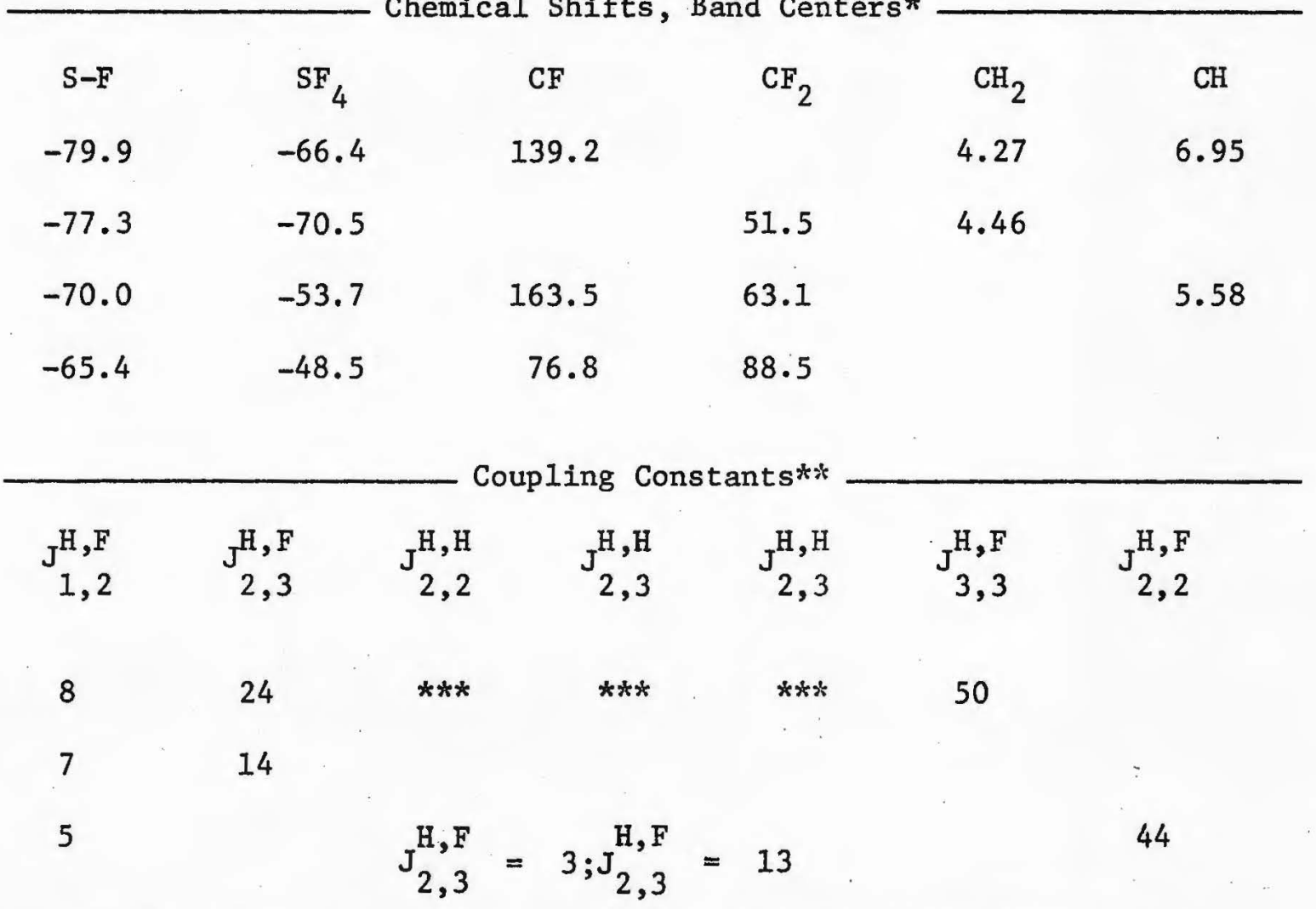

*Chemical shifts in parts per million upfield from $\mathrm{CFCl}_{3}$ internal standard or downfield from $\mathrm{Si}\left(\mathrm{CH}_{3}\right){ }_{4}$ internal standard.

$* *$ Measured in cycles per second.
***Data unavailable as a detailed analysis of this compound is incomplete; $\mathrm{J}_{2,3}^{\mathrm{H}}+\mathrm{J}_{2,3}^{\mathrm{H}, \mathrm{H}}=11$ cps.
+Structure unknown. 
In addition to $\mathrm{SF}_{5} \mathrm{Br}$, two other compounds, $\mathrm{SF}_{5} \mathrm{Cl}$ and $\mathrm{S}_{2} \mathrm{~F}_{10}$, have been studied.

$\mathrm{SF}_{5} \mathrm{Cl}$ is a less active potential reagent for introducing $\mathrm{SF}_{5}$ groups into simple molecular structures than the bromo-analog as indicated by the reaction conditions (4). Nevertheless, its reactions have been intensely studied. $\mathrm{SF}_{5} \mathrm{Cl}$ is a colorless gas (b.p. $\left.-21^{\circ}\right)$ that reacts with aqueous alkali solutions very rapidly (7). Table V lists the reactions of $\mathrm{SF}_{5} \mathrm{Cl}$ with unsaturated systems (8-11).

Dehydrdhalogenation of the adducts in Table $V$ produced the corresponding unsaturated $\mathrm{SF}_{5}$ compounds $(8,9)$ as shown in Table VI. The extent to which these and other $\mathrm{SF}_{5}$ compounds are used in preparing new and interesting derivatives is illustrated in Table VII $(8-15)$.

It is reported that arylsulfur pentafluorides cannot be prepared using $\mathrm{SF}_{5} \mathrm{Cl}(16)$.

The first synthesis of aryl sulfur pentafluorides was accomplished by the reaction of aryl disulfides or arylsulfur trifluorides with silver difluoride at $120^{\circ} \mathrm{C}$ in a teflon reactor.

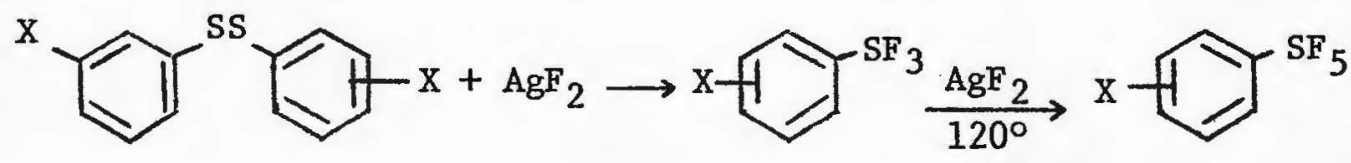

Later a modified procedure involved the addition of bis-(pheny1)disulfide to five molar equivalents of silver difluoride, suspended in "Freon 113," in a copper reactor. This was found particularly useful for the reaction of bis-(m- and $p-n i t r o p h e n y l)$ disulfides with silver difluoride. The above procedure has also been employed for the preparation of an aromatic compound substituted with two sulfur pentafluoride 
groups (17) as shown below:

TABLE V

$\mathrm{SF}_{5} \mathrm{Cl}$ ADDUCTS WITH OLEFINS

Reactants

$$
\begin{aligned}
& \mathrm{SF}_{5} \mathrm{C} 1+\mathrm{CH}_{2}=\mathrm{CH}_{2} \\
& \mathrm{SF}_{5} \mathrm{C} 1+\mathrm{CFC} 1=\mathrm{CF}_{2} \\
& \mathrm{SF}_{5} \mathrm{Cl}+\mathrm{CF}_{2}=\mathrm{CF}_{2}
\end{aligned}
$$$$
\mathrm{SF}_{5} \mathrm{Cl}+\mathrm{CH}_{3} \mathrm{CH}=\mathrm{CH}_{2}
$$$$
\mathrm{SF}_{5} \mathrm{Cl}+\mathrm{CF}_{2}=\mathrm{CFH}
$$$$
\mathrm{SF}_{5} \mathrm{Cl}+\mathrm{CF}_{2}=\mathrm{CFCl}
$$$$
\mathrm{SF}_{5} \mathrm{Cl}+\mathrm{CH}_{2}=\mathrm{CHC} 1
$$$$
\mathrm{SF}_{5} \mathrm{C} 1+\mathrm{CF}_{3} \mathrm{CF}=\mathrm{CF}_{2}
$$$$
\mathrm{SF}_{5} \mathrm{Cl}+\mathrm{CH} \equiv \mathrm{CH}
$$$$
\mathrm{SF}_{5} \mathrm{C} 1+\mathrm{CH}_{3} \mathrm{C} \equiv \mathrm{CH}
$$$$
\mathrm{SF}_{5} \mathrm{C} 1+\square
$$$$
3 \text { hrs. } 100^{\circ}
$$$$
6 \text { hrs. } 150^{\circ}
$$$$
10 \text { hrs. } 100^{\circ}
$$$$
6 \text { hrs. } 150^{\circ}
$$

Reaction Conds.

$10 \mathrm{hrs} .90^{\circ}$

$10 \mathrm{hrs} \cdot 100^{\circ}$

$10 \mathrm{hrs} .90^{\circ}$
U.V.

$$
\text { U.V. }
$$$$
4 \text { hrs. } 90^{\circ}
$$$$
\text { (or U.V.) }
$$

$$
\text { R.T. }
$$

188-190

B.P. $\left({ }^{\circ} \mathrm{C}\right)$ Products (Adducts)

$92 \quad \mathrm{SF}_{5} \mathrm{CH}_{2} \mathrm{CH}_{2} \mathrm{Cl}+$

171-172 $\mathrm{SF}_{5}\left(\mathrm{CH}_{2} \mathrm{CH}_{2}\right)_{2} \mathrm{Cl}$

79.5-82 $\mathrm{SF}_{5} \mathrm{CFClCF}_{2} \mathrm{Cl}$

$47 \quad \mathrm{SF}_{5} \mathrm{CF}_{2} \mathrm{CF}_{2} \mathrm{Cl}+$

$99 \quad \mathrm{SF}_{5}\left(\mathrm{CF}_{2} \mathrm{CF}_{2}\right)_{2} \mathrm{Cl}+$

$142 \mathrm{SF}_{5}\left(\mathrm{CF}_{2} \mathrm{CF}_{2}\right)_{3} \mathrm{C} 1$

$109 \mathrm{SF}_{5} \mathrm{CH}_{2} \mathrm{CHClCH}_{3}$

59-61 $\mathrm{SF}_{5} \mathrm{CHF}-\mathrm{CF}_{2} \mathrm{Cl}$

80-83 $\mathrm{SF}_{5} \mathrm{CF}_{2} \mathrm{CFCl}_{2}$

$108 \quad \mathrm{SF}_{5} \mathrm{CH}_{2} \mathrm{CHCl}_{2}(35 \%)+$

$72 / 9 \mathrm{~mm} \quad \mathrm{SF}_{5} \mathrm{CH}_{2} \mathrm{CHClCH}_{2} \mathrm{CHCl}_{2}$

(25\%)

71-73 $\mathrm{SF}_{5} \mathrm{CF}_{2} \mathrm{CFClCF}_{3}+$

$\mathrm{CF}_{3} \mathrm{SF}_{5} \mathrm{CFClCF}_{2}$

$\mathrm{SF}_{5} \mathrm{CH}=\mathrm{CHCl}$

$\mathrm{SF}_{5} \mathrm{CH}=\mathrm{CClCH}_{3}$<smiles>SCC1CCCCC1Cl</smiles>

$\mathrm{SF}_{5} \mathrm{Cl}+\mathrm{CH}_{3}-\mathrm{O}-\mathrm{C}-\mathrm{O}-\mathrm{C}\left(\mathrm{CH}_{3}\right)=\mathrm{CH}_{2}$

$1 \mathrm{hr}, 100^{\circ}$

$\mathrm{SF}_{5} \mathrm{C} 1+\mathrm{CH}_{2}=\mathrm{C}=0$

20 hrs. R.T.

126

$\mathrm{SF}_{5} \mathrm{CH}_{2} \stackrel{\mathrm{O}}{\mathrm{C}-\mathrm{CH}_{3}}$

$\mathrm{SF}_{5} \mathrm{Cl}+\mathrm{CH}_{3}-\mathrm{C}-\mathrm{O}-\mathrm{CH}=\mathrm{CH}_{2} \quad 1 \mathrm{hr} .50^{\circ}$

102

$\mathrm{SF}_{5} \mathrm{CH}_{2} \stackrel{\mathrm{O}}{\mathrm{C}}-\mathrm{C} 1$

$36 / 2.7 \mathrm{~mm}$

$\mathrm{SF}_{5} \mathrm{CH}_{2} \mathrm{CHClO}-\mathrm{C}-\mathrm{CH}_{3}$

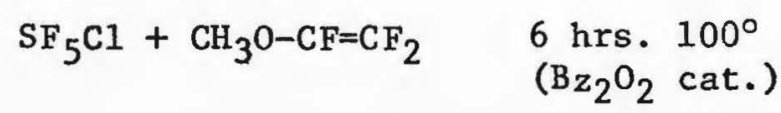

$\mathrm{SF}_{5} \mathrm{CF}_{2} \mathrm{CF}_{1} \mathrm{ClOCH}_{3}$

$\mathrm{SF}_{5} \mathrm{Cl}+\mathrm{C}_{2} \mathrm{H}_{5} \mathrm{O}-\mathrm{CF}=\mathrm{CF}_{2} \quad 6 \mathrm{hrs} .100^{\circ}$ or $\left(\mathrm{Bz}_{2} \mathrm{O}_{2}\right)$

$\mathrm{SF}_{5} \mathrm{CF}_{2} \mathrm{CFC} \mathrm{CC}_{2} \mathrm{H}_{5}$ 
TABLE VI

$\mathrm{SF}_{5}$ OLEFINS

Reactants

$\mathrm{SF}_{5} \mathrm{CH}_{2} \mathrm{CH}_{2} \mathrm{Cl}+\mathrm{KOH}$

$\mathrm{SF}_{5} \mathrm{CH}_{2} \mathrm{CHClCH}_{3}+\mathrm{KOH}$

$\Upsilon^{\mathrm{SF}_{5}}+\mathrm{KOH}$

$\mathrm{SF}_{5} \mathrm{CHClCH}_{3}+\mathrm{KOH}$
Reaction Conds.

$1 \mathrm{hr}$. (ethanol as solvent)

$2.5 \mathrm{hr}$. (methanol) $\quad 80-82$

$15 \mathrm{~min}$. (ethano1)

161
20 min. (pet ether) $75^{\circ} \mathrm{C}$

TABLE VII

DERIVATIVES OF $\mathrm{SF}_{5}$ COMPOUNDS

Reactants
$\mathrm{SF}_{5} \mathrm{CH}=\mathrm{CH}_{2}+\mathrm{Cl}_{2}$

$\mathrm{SF}_{5} \mathrm{CF}=\mathrm{CF}_{2}+\mathrm{Cl}_{2}$

U.V.

$\mathrm{SF}_{5} \mathrm{CF}=\mathrm{CF}_{2}+\mathrm{CF}=\mathrm{CF}_{2} \quad 10-60$ atm. $50-100^{\circ} \mathrm{C}$

$\mathrm{SF}_{5} \mathrm{C} \equiv \mathrm{CH}+\mathrm{CH}_{3} \mathrm{OH}$

$\mathrm{OH}^{-}$as cat.

144

115

B.P. $\left({ }^{\circ} \mathrm{C}\right)$

111

79.5-82

$\mathrm{SF}_{5} \mathrm{CFClCF}_{2} \mathrm{Cl}$

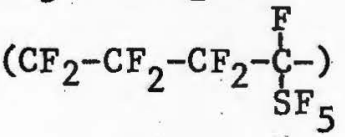<smiles>CO/C=C\[Sb]</smiles>

$\mathrm{SF}_{5} \mathrm{CH}=\mathrm{CHCl}+\mathrm{CH}_{3} \mathrm{OH}$

$\mathrm{OH}^{-}$as cat. 
TABLE VII (cont.)

\section{$\underline{\text { Reactants }}$}

$\mathrm{SF}_{5} \mathrm{C} \equiv \mathrm{CH}+\mathrm{CH}_{2} \mathrm{~N}_{2}$

$\mathrm{SF}_{5} \mathrm{C} \equiv \mathrm{CH}+\mathrm{CH}_{2}=\mathrm{CHCH}=\mathrm{CH}_{2}$

$120^{\circ}$

Chloranil

$$
\begin{aligned}
& \mathrm{SF}_{5}-\mathrm{C}=\mathrm{C}-\mathrm{CH} \\
& \mathrm{H}_{2} \mathrm{C} \prod_{\mathrm{C}=\mathrm{C}}^{\mathrm{CH}_{2}} \\
& \mathrm{H}_{3} \mathrm{C} \mathrm{CH}_{3}
\end{aligned}
$$

Reaction ronds.

B.P. $\left({ }^{\circ} \mathrm{C}\right)$

Products

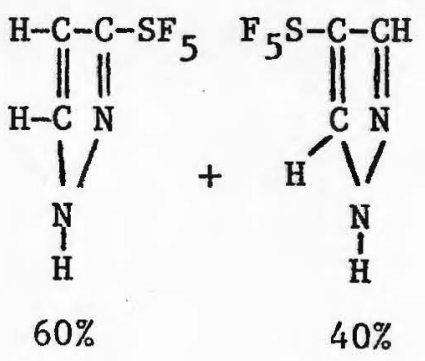

$\mathrm{SF}_{5} \mathrm{CH}=\mathrm{CHC} 1+\mathrm{Br}_{2}$

U.v.

12 hrs. $35^{\circ}$

$1-1 / 2$ hrs. $140^{\circ}$

$\mathrm{SF}_{5} \mathrm{CBr}=\mathrm{CHCl}+\mathrm{Zn}$

$\mathrm{SF}_{5} \mathrm{CH}=\mathrm{CHCl}+\mathrm{KOH}$

$\mathrm{SF}_{5} \mathrm{CF}_{2} \mathrm{CFClOCH}_{3}+\mathrm{ETOH}$

$80-85^{\circ} \stackrel{\mathrm{H}_{2} \mathrm{SO}_{4}}{\longrightarrow}$

$\mathrm{SF}_{5}-\mathrm{C}=\mathrm{C}-\mathrm{H}$

Pt. gauze, $575^{\circ}$

${ }_{\mathrm{HC}}^{\mathrm{H}_{2} \mathrm{C}}=\stackrel{\mathrm{CH}}{\mathrm{CH}}^{\mathrm{CH}_{2}}$

$\mathrm{HC}=\mathrm{CH}$
$\mathrm{SF}_{5} \mathrm{C} \equiv \mathrm{CH}+\mathrm{CH}_{2}=\mathrm{C}-\left.\right|_{\mathrm{C}=\mathrm{CH}_{2}} ^{\mathrm{CH}_{3}} 120-140^{\circ}$
147<smiles>[Sb][Sb]1CCCCCC1</smiles><smiles>Cc1ccc([Sb])cc1C</smiles>

$70(13 \mathrm{~mm}) \quad \mathrm{SF}_{5} \mathrm{CHBrCHBrC1}$

$50(52 \mathrm{~mm}) \quad \mathrm{SF}_{5} \mathrm{CBr}=\mathrm{CHC} 1$

6

$\mathrm{SF}_{5} \mathrm{C} \equiv \mathrm{CH}$

6

$\mathrm{SF}_{5} \mathrm{C} \equiv \mathrm{CH}$

$\mathrm{SF}_{5} \mathrm{CF}_{2} \mathrm{COOET}$

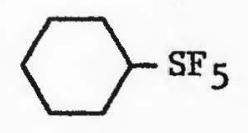


TABLE VII (cont.)

\begin{tabular}{|c|c|c|c|}
\hline Reactants & Reaction Conds. & B.P. $\left({ }^{\circ} \mathrm{C}\right)$ & Products \\
\hline $\mathrm{SF}_{5} \mathrm{CH}=\mathrm{CH}_{2}+\mathrm{Br}_{2}$ & U.V. (37 min.) & $50-52 / 22 \mathrm{~mm}$ & $\mathrm{SF}_{5} \mathrm{CHBrCH}_{2} \mathrm{Br}$ \\
\hline $\mathrm{SF}_{5} \mathrm{CHBrCH}_{2} \mathrm{Br}+\mathrm{K}_{2} \mathrm{CO}_{3}$ & $33^{\circ}(75 \mathrm{~min})$. & 86 & $\mathrm{SF}_{5} \mathrm{CBr}=\mathrm{CH}_{2}$ \\
\hline $\mathrm{SF}_{5} \mathrm{CBr}=\mathrm{CH}_{2}+\mathrm{Br}_{2}$ & 2 hrs. U.V. & $42 / 0.5 \mathrm{~mm}$ & $\mathrm{SF}_{5} \mathrm{CBr}_{2} \mathrm{CH}_{2} \mathrm{Br}$ \\
\hline $\mathrm{SF}_{5} \mathrm{CH}_{2} \mathrm{CHO}+\left(\mathrm{CH}_{3} \mathrm{CO}\right)_{2} \mathrm{O}$ & & $49 / 0.15 \mathrm{~mm}$ & $\mathrm{SF}_{5} \mathrm{CH}_{2} \mathrm{CH}\left(\mathrm{O}_{2} \mathrm{CCH}_{3}\right)_{2}$ \\
\hline $\mathrm{SF}_{5} \mathrm{CH}_{2} \mathrm{COCl}+\mathrm{H}_{2} \mathrm{O}$ & $20 \mathrm{~min} .47^{\circ}$ & m.p. $62-64$ & $\mathrm{SF}_{5} \mathrm{CH}_{2} \mathrm{COOH}$ \\
\hline $\mathrm{SF}_{5} \mathrm{CH}_{2} \mathrm{COCl}+\mathrm{C}_{2} \mathrm{H}_{5} \mathrm{OH}$ & & $60 / 41 \mathrm{~mm}$ & $\mathrm{SF}_{5} \mathrm{CH}_{2} \mathrm{CO}_{2} \mathrm{C}_{2} \mathrm{H}_{5}$ \\
\hline $\begin{array}{c}\mathrm{SF}_{5} \mathrm{CH}_{2} \mathrm{COCl}+\mathrm{C}_{6} \mathrm{H}_{5} \mathrm{NH}_{2} \\
\mathrm{SF}_{5} \mathrm{CH}_{2} \mathrm{CHClO}-\stackrel{9}{\mathrm{C}}-\mathrm{CH}_{3}+\end{array}$ & & $\mathrm{m} \cdot \mathrm{p} \cdot 114-116$ & $\mathrm{SF}_{5} \mathrm{CH}_{2} \mathrm{CONHC}_{6} \mathrm{H}_{5}$ \\
\hline $\mathrm{KOH}+\mathrm{P}_{2} \mathrm{O}_{5}$ & & . & $\mathrm{SF}_{5} \mathrm{CH}_{2} \mathrm{CHO}$ \\
\hline $\mathrm{SF}_{5} \mathrm{CH}_{2} \mathrm{COCl}+\mathrm{NH}_{3}$ & & $m \cdot p \cdot 143-144$ & $\mathrm{SF}_{5} \mathrm{CH}_{2} \mathrm{CONH}_{2}$ \\
\hline $\mathrm{SF}_{5} \mathrm{C} \equiv \mathrm{CH}+\mathrm{AgNO}_{3}$ & $0^{\circ}$ & $\begin{array}{l}\text { Decomp. at } \\
\text { R.T. }\end{array}$ & $\mathrm{SF}_{5} \mathrm{C} \equiv \mathrm{CAg}$ \\
\hline $\mathrm{SF}_{5} \mathrm{CF}=\mathrm{CF}_{2}+\mathrm{IF}$ & 3 hrs. $140-150^{\circ}$ & $80-82$ & $\mathrm{SF}_{5} \mathrm{CFICF}_{3}$ \\
\hline $\mathrm{SF}_{5} \mathrm{CFICF}_{3}+\mathrm{CH}_{2}=\mathrm{CH}_{2}$ & U.V. & 98 & $\mathrm{SF}_{5} \mathrm{CFCF}_{3} \mathrm{CH}_{2} \mathrm{CH}_{2} \mathrm{I}$ \\
\hline $\mathrm{SF}_{5} \mathrm{CF}=\mathrm{CF}_{2}+\mathrm{O}_{3}$ & $\begin{array}{c}\text { FC-43 (solvent) } \\
-80^{\circ}\end{array}$ & & $\mathrm{SF}_{5} \mathrm{O}-\mathrm{CF}_{2}-\mathrm{COF}$ \\
\hline $\mathrm{SF}_{5} \mathrm{CF}=\mathrm{CF}_{2}+\mathrm{O}_{2}$ & No Solvent $\left(45^{\circ}\right)$ & & $\mathrm{SF}_{5} \mathrm{OCF}_{2} \mathrm{COF}$ \\
\hline $\mathrm{SF}_{5} \mathrm{OCF}_{2} \mathrm{COF}+\mathrm{H}_{2} \mathrm{O}$ & & & $\mathrm{SF}_{5} \mathrm{OCF}_{2} \mathrm{COOH}$ \\
\hline $\mathrm{SF}_{5} \mathrm{OCF}_{2} \mathrm{COOH}+\mathrm{NH}_{3}$ & & & $\mathrm{SF}_{5} \mathrm{OCF}_{2} \mathrm{CONH}_{2}$ \\
\hline $\mathrm{SF}_{5} \mathrm{OCF}_{2} \mathrm{COF}+\mathrm{CH}_{3} \mathrm{OH}$ & & & $\mathrm{SF}_{5} \mathrm{OCF}_{2} \mathrm{COOCH}_{3}$ \\
\hline $\mathrm{SF}_{5} \mathrm{CF}_{2} \mathrm{COOET}+\mathrm{NH}_{3}$ & $\mathrm{ET}_{2} \mathrm{O}$ as solvent & & $\mathrm{SF}_{5} \mathrm{CF}_{2} \mathrm{CONH}_{2}$ \\
\hline $\mathrm{SF}_{5} \mathrm{CF}_{2} \mathrm{CONH}_{2}$ & (alc. $\mathrm{NaOH}) \frac{\mathrm{H}_{2} \mathrm{SO}_{4}}{\Delta}$ & & $\mathrm{SF}_{5} \mathrm{CF}_{2} \mathrm{COOH}$ \\
\hline $\mathrm{SF}_{4} \mathrm{CF}_{2} \mathrm{CO}_{2} \mathrm{Ag}+\mathrm{I}_{2}$ & Heat & & $\mathrm{SF}_{5} \mathrm{CF}_{2} \mathrm{I}$ \\
\hline
\end{tabular}



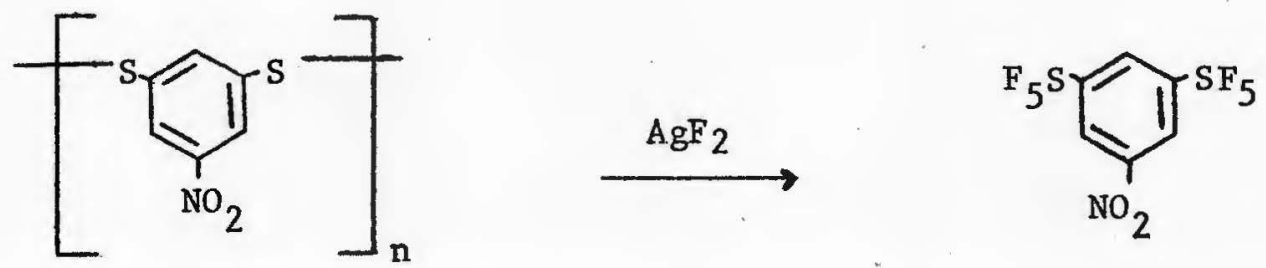

The sulfur pentafluoride group, like the trifluoromethyl group, is electron withdrawing and meta directing towards electrophilic aromatic substitution. Representative reactions of phenyl sulfur pentafluoride and some arylsulfur pentafluorides are shown in Table VIII (17).

Disulfur decafluoride $\left(\mathrm{S}_{2} \mathrm{~F}_{10}\right)$ is a colorless liquid boiling at $29^{\circ}$ (18). In practice, it has been found that despite the fact that the S-S bond in disulfur decafluoride breaks readily at $150^{\circ} \mathrm{C}(16)$, the reaction of $\mathrm{S}_{2} \mathrm{~F}_{10}$ with olefins proceeds at best in very poor yield and in other cases not at all. It appears that $\mathrm{S}_{2} \mathrm{~F}_{10}$ gives as its principal reaction, destructive oxidations due to the reactions:

$$
\begin{aligned}
& \mathrm{S}_{2} \mathrm{~F}_{10} \longrightarrow 2 \mathrm{SF}_{5} \\
& \mathrm{SF}_{5} \longrightarrow \mathrm{SF}_{4}+\mathrm{F}
\end{aligned}
$$

and that as a reagent for introducing the $\mathrm{SF}_{5}$ group into organic molecules it is much less efficient than $\mathrm{SF}_{5} \mathrm{Cl}$, not to mention $\mathrm{SF}_{5} \mathrm{Br}(4,20)$. Table IX gives the reactions of $\mathrm{S}_{2} \mathrm{~F}_{10}$ with some olefins (20-22).

The mechanism for these reactions seems to undergo a radical addition pathway. In the case of $\mathrm{SF}_{5} \mathrm{Cl}$ and $\mathrm{SF}_{5} \mathrm{Br}$ the $\mathrm{SF}_{5} \cdot$ radical attacks the carbon of the fluoroolefins carrying the most hydrogens $(8,9,13)$. The proposed elementary steps are as follows $(8-9)$ :

$$
\begin{aligned}
& \mathrm{SF}_{5}{ }^{\circ}+\mathrm{R} \longrightarrow \mathrm{RSF}_{5}{ }^{\circ} \\
& \mathrm{RSF}_{5}{ }^{\circ}+\mathrm{SF}_{5} \mathrm{X} \longrightarrow \mathrm{RSF}_{5} \mathrm{X}+\mathrm{SF}_{5} \cdot \\
& \mathrm{x}=\mathrm{Cl}, \mathrm{Br}
\end{aligned}
$$


TABLE VIII

REACTIONS OF ARYLSULFUR PENTAFLUORIDES

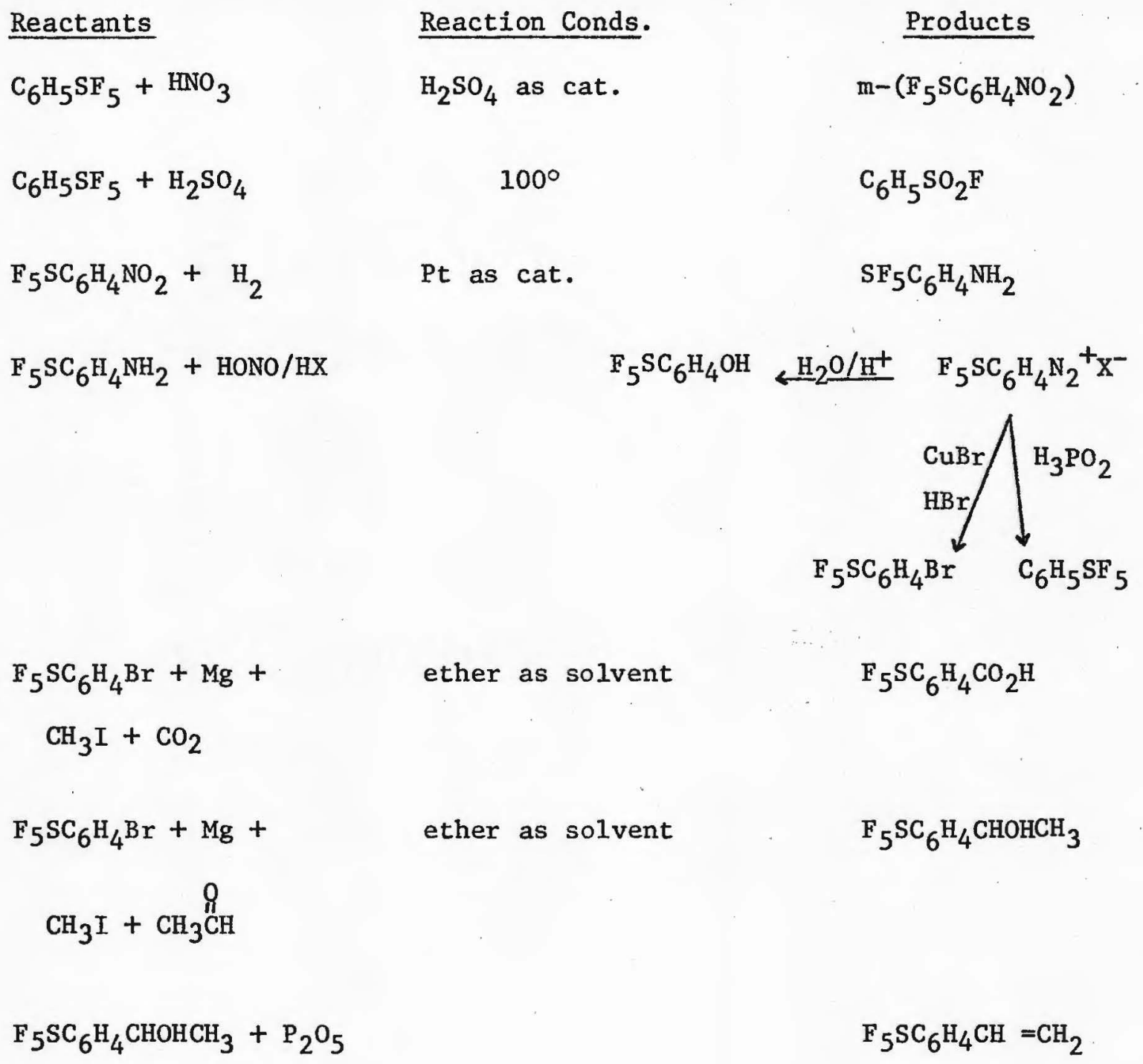

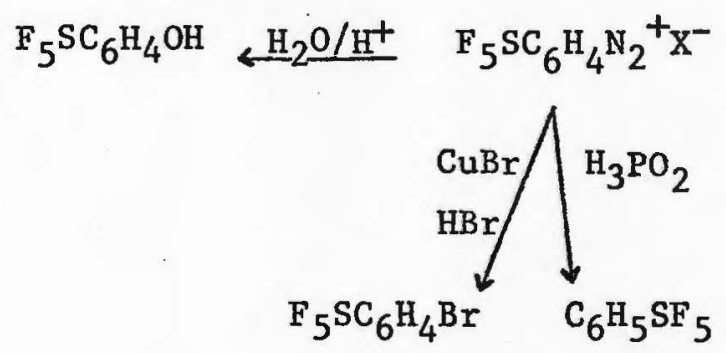


TABLE IX

REACTIONS OF $\mathrm{S}_{2} \mathrm{~F}_{10}$ WITH OLEFINS

Reactants

$\mathrm{S}_{2} \mathrm{~F}_{10}+\mathrm{CH}_{3} \mathrm{CH}=\mathrm{CH}_{2}$

$\mathrm{S}_{2} \mathrm{~F}_{10}{ }^{+} \mathrm{CH}_{2}=\mathrm{CHC} 1$

$\mathrm{S}_{2} \mathrm{~F}_{10}{ }^{+} \mathrm{CF}_{2}=\mathrm{CF}_{2}$

$\mathrm{s}_{2} \mathrm{~F}_{10}+0$

$\mathrm{S}_{2} \mathrm{~F}_{10}{ }^{+} \mathrm{CH}_{2}=\mathrm{CHCl}$

$\mathrm{S}_{2} \mathrm{~F}_{10}+\mathrm{CH}_{2}=\mathrm{CHBr}$

$\mathrm{S}_{2} \mathrm{~F}_{10}+\mathrm{CH}_{2}=\mathrm{CHF}$

$\mathrm{S}_{2} \mathrm{~F}_{10}+\mathrm{IC}_{2} \mathrm{~F}_{4} \mathrm{I}$

4 hrs. $150^{\circ}$

$\mathrm{S}_{2} \mathrm{~F}_{10}+\mathrm{CH}_{2}=\mathrm{C}=\mathrm{CH}_{2} \quad 125^{\circ}$

$125^{\circ}$

$125-140^{\circ}$

$125-140^{\circ}$

$140-150^{\circ}$
$\mathrm{S}_{2} \mathrm{~F}_{10}+\mathrm{CF}_{3} \mathrm{CF}=\mathrm{CF}_{2}$

\section{B.P. $\left({ }^{\circ} \mathrm{C}\right)$ Products}

high b.p. not identified residue

110-120 $\quad \mathrm{SF}_{5} \mathrm{CH}_{2}-\mathrm{CHC} 1 \mathrm{SF}{ }_{5}$

$96^{\circ} \mathrm{C} \quad \mathrm{SF}_{5} \mathrm{CF}_{2}-\mathrm{CFSF}_{5} \mathrm{CF}_{3}$

soften at white solid $260^{\circ}$

10 hrs. $180^{\circ}\left(\mathrm{CCl}_{3} \mathrm{~F}\right) \quad 147^{\circ}$ solvent

$\mathrm{CH}_{2} \mathrm{FCHFCH}_{2} \mathrm{CHFSF}_{5}$

$\mathrm{CH}_{2}=\mathrm{CHCHFCH}_{2} \mathrm{SF}_{5}$

$\mathrm{SF}_{5}\left(\mathrm{C}_{2} \mathrm{~F}_{4}\right) \mathrm{I}$

$\mathrm{SF}_{5}\left(\mathrm{C}_{2} \mathrm{~F}_{4}\right) \mathrm{n} \mathrm{I}$,

$n=4 \sim 9$

$\mathrm{SF}_{5} \mathrm{CH}_{2} \mathrm{CF}_{2} \mathrm{CH}_{2} \mathrm{~F}$

$\mathrm{S}_{2} \mathrm{~F}_{10}+\mathrm{C}_{2} \mathrm{H}_{5} \mathrm{C} \equiv \mathrm{CH}$ 
With ultraviolet excitation homolysis of the $\mathrm{SF}_{5} \mathrm{X}$ molecule produces both $\mathrm{SF}_{5} \cdot$ and $\mathrm{X}$ - radicals which then compete with each other for the substrates as illustrated below (23-24):

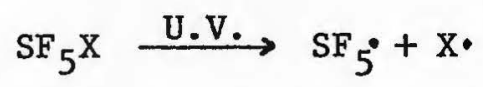

$$
\begin{aligned}
& \mathrm{SF}_{5^{\circ}}+\mathrm{R} \longleftrightarrow \mathrm{SF}_{5} \mathrm{R} \text {. } \\
& \mathrm{SF}_{5} \mathrm{R}^{\cdot}+\mathrm{SF}_{5} \mathrm{X} \longrightarrow \mathrm{SF}_{5} \mathrm{RX}+\mathrm{SF}_{5} \\
& \mathrm{X} \cdot \mathrm{t} \longrightarrow \mathrm{RX} \cdot \\
& \mathrm{RX} \cdot+\mathrm{SF}_{5} \mathrm{X} \longrightarrow \mathrm{RX}_{2}+\mathrm{SF}_{5} \text {. }
\end{aligned}
$$

$\mathrm{SF}_{5}$ compounds exhibit a wide range of useful and interesting properties. For example, $\mathrm{SF}_{5}(25), \mathrm{CF}_{3} \mathrm{SF}_{5}(25), \mathrm{SF}_{5} \mathrm{CF}=\mathrm{CF}_{2}$ (26), and $\mathrm{SF}_{5}$-oxetanes (27) possess unusual dielectric strength while $\mathrm{S}_{2} \mathrm{~F}_{10}$ (25), and $\mathrm{SF}_{5} \mathrm{CF}=\mathrm{CF}_{2}$ (28) are biologically active. In addition, $\mathrm{SF}_{6}$ (25), $\mathrm{RFSF}_{5}(29), \mathrm{SF}_{5}$-oxetanes (27) and $\mathrm{S}_{2} \mathrm{~F}_{10}$ (25) have high chemical stability towards concentrated acids and bases. It is expected that new $\mathbf{S F}_{5}$ compounds will provide the basis for further study regarding the above properties and new $\mathrm{SF}_{5}$-olefins should be useful in preparing surface active polymers.

The purposes of this work were to further study the reaction of $\mathrm{SF}_{5} \mathrm{Br}$ with fluoroolefins and to extend the $\mathrm{SF}_{5} \mathrm{Br}$ addition reaction to compounds containing a triple bond. Four new compounds were prepared:

$$
\begin{aligned}
& \mathrm{SF}_{5} \mathrm{Br}+\mathrm{CH}_{2}=\mathrm{CFCl} \longrightarrow \mathrm{SF}_{5} \mathrm{CH}_{2} \mathrm{CFClBr} \\
& \mathrm{SF}_{5} \mathrm{Br}+\mathrm{CF}_{2}=\mathrm{CClH} \longrightarrow \mathrm{SF}_{5} \mathrm{CF}_{2} \mathrm{CHClBr} \\
& \mathrm{SF}_{5} \mathrm{Br}+\mathrm{CF}_{3} \mathrm{C} \equiv \mathrm{CH} \longrightarrow \mathrm{SF}_{5} \mathrm{CH}=\mathrm{C}\left(\mathrm{CF}_{3}\right) \mathrm{Br} \\
& \mathrm{SF}_{5} \mathrm{Br}+\mathrm{CH}_{3} \mathrm{C} \equiv \mathrm{CH} \longrightarrow \mathrm{SF}_{5} \mathrm{CH}=\mathrm{C}\left(\mathrm{CH}_{3}\right) \mathrm{Br}
\end{aligned}
$$


All these new compounds are clear, water-white readily distillable 1iquids. They have been characterized via their infrared spectra, mass spectra, and nuclear magnetic spectra. Particularly interesting was the fact that reaction (19) produced two isomers while all other reactions yielded essentially only one product. 


\section{CHAPTER II}

\section{EXPERIMENTAL METHODS}

\section{Vacuum System}

The vacuum system used in this work consisted of a manifold connected to a Welch Duo-Seal rotary pump. The manifold was constructed of $22 \mathrm{~mm}$ and $8 \mathrm{~mm}$ I.D. Pyrex glass tubing and was connected to a two leg mercury manometer and four taps. The taps were Eck and Krebs 2-mm high vacuum stopcocks, to which were connected Pyrex 10/30 outer glass joints. The rotary pump was protected by a concentric trap which was cooled with liquid nitrogen. A Televac thermocouple gauge was used to monitor the vacuum, which usually attained $10^{-3}-10^{-2}$ torr. All joints were lubricated with Apiezon-M grease. The vacuum system is illustrated in Figure I.

\section{$\underline{\text { Reaction Vessels }}$}

Pyrex-Glass Reaction Vessels. For those reactions occurring at room temperature 1, 2, or 3-1iter Pyrex glass vessels were used. These vessels were equipped with a cold finger at the bottom for condensing the materials and were closed with $2 \mathrm{~mm}$ high vacuum Teflon stopcocks. These vessels were tipped with $10 / 30$ joints for attaching to the vacuum line.

\section{Metal High Pressure Vessel}

Sulfur bromide pentafluoride was prepared in a $75 \mathrm{ml}$ Monel vesse1 equipped with a Whitey-Stainless steel valve tipped with a brass $10 / 30$ 


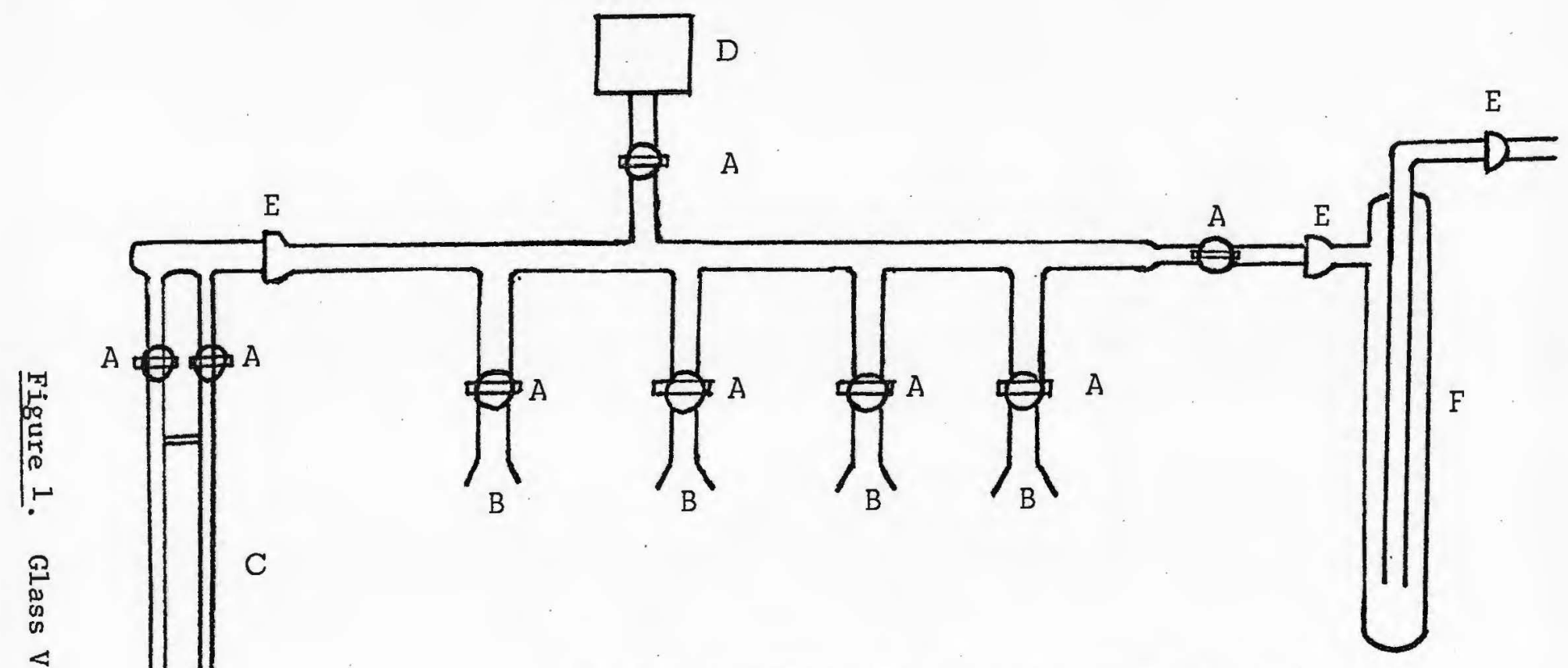

A. Eck and Krebs $2 \mathrm{~mm}$ high vacuum stopcock

B. 10/30 क Outer Joint

C. Two-leg Mercury Manometer

D. Thermocouple Gauge

E. 18/9 Ball Joints

F. Glass Trap 
inner joint. Reactions of $\mathrm{SF}_{5} \mathrm{Br}$ requiring heat were carried out in a $200 \mathrm{~cm}^{3}$ stainless steel vessel equipped with a brass valve tipped with a brass $10 / 30$ inner joint. The pressure vessel was placed in an oven heated to approximately $100^{\circ}$.

\section{Physical Methods}

Fractional Distillation. The products of the reactions were purified by fractional distillation. A Bantum-ware (Kontes) distillation apparatus was used. The distillation column was connected to atmosphere through a $-78^{\circ}$ trap.

Gas Chromatography. The purity of the products was checked by gas chromatography by using an Aerograph Autoprep (Mode1 A-700) gas chromatograph. Separations were carried out with a $10^{\prime} \times 3 / 8^{\prime \prime}$ column containing $20 \%$ Carbowax absorbed on "Chromosorb W".

Molecular Weights. Molecular weights were determined on the vacuum line by the vapor density method. A $209.6 \mathrm{~cm}^{3}$ Pyrex bulb, equipped with a Teflon stopcock was used.

\section{Infrared Spectra}

Infrared spectra were obtained over the range $4000-250 \mathrm{~cm}^{-1}$ on a Perkin-Elmer 467 spectrometer. Gaseous samples were contained in a $8.25 \mathrm{~cm}$ Monel cell fitted with $\mathrm{AgCl}$ windows and a Whitey-Brass valve which was connected to a brass $10 / 30$ inner joint for attachment to a vacuum line.

Nuclear Magnetic Resonance Spectra.

The proton spectra were recorded on a Varian Model A-60 or a Varian model EM 300X NMR spectrometers. 


\section{Mass Spectra}

Mass spectra were taken on a CEC 21-110 B double focus Mass Spectrometer equipped with a $6 \mathrm{KV}$ ion accelator and operated at 70 volts. Perfluorokerosine (PFK) was used on an internal standard.

\section{Chemical Analysis}

Chemical analyses were performed by Beller Microanalytical Laboratory in Gottingen, West Germany.

\section{Reagents}

Pentafluorosulfur Bromide. $\mathrm{SF}_{5} \mathrm{Br}$ was prepared by the method of Berry and Fox (6) in which $\mathrm{S}_{2} \mathrm{~F}_{10}$ and $\mathrm{Br}_{2}$ are heated at $150^{\circ}$ in a Monel reactor for 16 hours. No attempts were made to purify the $\mathrm{SF}_{5} \mathrm{Br}$ (possible contaminants are $\mathrm{SF}_{6}, \mathrm{SF}_{4}, \mathrm{~S}_{2} \mathrm{~F}_{10}$ and $\mathrm{Br}_{2}$ ) other than transfering it from the Monel reactor at -60 to $-50^{\circ}$.

\section{1-Chloro-1-fluoroethylene}

The 1-Chloro-1-fluoroethylene was purchased from Peninsular ChemResearch and used without further purification. The purity was checked by infrared analysis.

\section{2-Chloro-1, 1-difluoroethylene}

2-Chloro-1, 1-difluoroethylene was purchased from Peninsular ChemResearch and was used without further purification. The purity was checked by infrared analysis.

\section{Methyl Acetylene}

Methy1 Acetylene was purchased from Air Products and Chemicals and was used without further purification. The purity was checked by 
infrared analysis.

Disulfurdecafluoride

$\mathrm{S}_{2} \mathrm{~F}_{10}$ was obtained as a gift from Dr. Meude Tremblay, Centre Canadien de Recherches et Perfectionnement des Armes (CARDE) Quebec, Canada. The molecular weight was found to be $254.8 \mathrm{~g} / \mathrm{mole}$ (theor. = $254.1 \mathrm{~g} / \mathrm{mole}$ ).

Bromine

Analytical reagent bromine was purchased from Mallinckrodt and was used without further purification. 
CHAPTER III

SYNTHESIS OF NEW ADDUCTS OF $\mathrm{SF}_{5} \mathrm{Br}$

REACTION WITH FLUOROOLEFINS AND ACETYLENES

\section{Introduction}

Pentafluorosulfur bromide reacts with

$$
\mathrm{CH}_{2}=\mathrm{CHCl}, \mathrm{CF}_{2}=\mathrm{CC} 1 \mathrm{H}, \mathrm{CF}_{3} \mathrm{C} \equiv \mathrm{CH} \text {, and } \mathrm{CH}_{3} \mathrm{C} \equiv \mathrm{CH}
$$

according to the following equations:

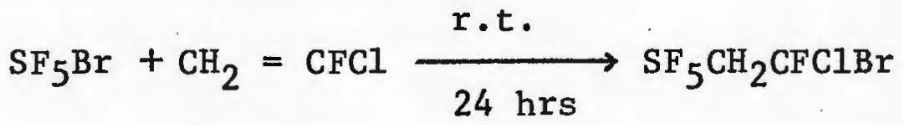

$$
\begin{aligned}
& \mathrm{SF}_{5} \mathrm{Br}+\mathrm{CF}_{2}=\mathrm{CC} 1 \mathrm{H} \frac{100^{\circ}}{14 \mathrm{~d}} \mathrm{SF}_{5} \mathrm{CF}_{2} \mathrm{CHC} 1 \mathrm{Br}
\end{aligned}
$$

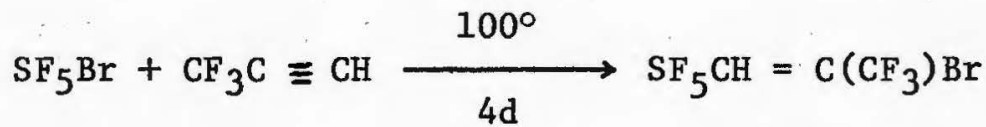

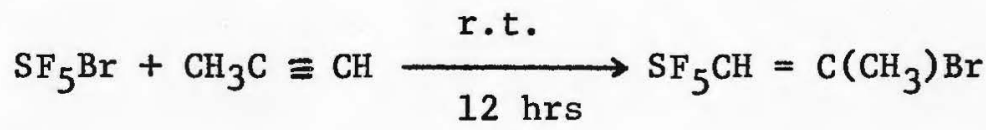

All of the new products were clear, colorless hydrolytically stable liquids. The product reported in equation (23) is in reality a mixture of two isomers (see below)<smiles>[13CH3]/C(Br)=C\c1ccccc1</smiles>

Entegegen Isomer and<smiles>[13CH3]/C(Br)=C/c1ccccc1</smiles>

Zusammen Isomer

that have been separated by gas chromatography and identified via their 
mass spectra, infrared spectra, and nmr spectra. For the other adducts, essentially one compound was found.

\section{EXPERIMENTAL}

Reaction of $\mathrm{SF}_{5} \mathrm{Br}$ with $\mathrm{CH}_{2}=\mathrm{CFC1}$

In a 3-1iter pyrex vessel, $6.25 \times 10^{-2}$ moles of $\mathrm{CH}_{2}=\mathrm{CFCl}$ and $7.3 \times 10^{-2}$ moles of $\mathrm{SF}_{5} \mathrm{Br}$ were condensed at $-196^{\circ}$. The vessel was warmed slowly from $-196^{\circ}$ to room temperature and the disappearance of yellow $\mathrm{SF}_{5} \mathrm{Br}$ and appearance of a colorless clear liquid were then observed. The reaction was allowed to stand overnight and was essentially complete after 24 hours. The clear liquid was distilled through a Kontes all-glass distillation apparatus and fraction boiling at $119^{\circ}$ was collected. The infrared spectrum of this product showed contamination by the starting olefin. The adduct was purified by washing with water, drying with $\mathrm{MgSO}_{4}$ and redistillation. The yield for this reaction was $28 \%$.

\section{Reaction of $\mathrm{SF}_{5} \mathrm{Br}$ with $\mathrm{CF}_{2}=\mathrm{CHCl}$}

The reaction of $\mathrm{SF}_{5} \mathrm{Br}$ with $\mathrm{CF}_{2}=\mathrm{CHCl}$ was first tried in a 1-liter Pyrex glass reaction vessel, in which $2.1 \times 10^{-2}$ moles of $\mathrm{CF}_{2} \mathrm{CHCl}$ and $2.4 \times 10^{-2}$ moles of $\mathrm{SF}_{5} \mathrm{Br}$ were condensed at $-196^{\circ}$. When warmed to room temperature, no reaction was evident until after 7 days. For 24 days the yield of this reaction was $14 \%$. An improved method was found in which $3.4 \times 10^{-2}$ moles of $\mathrm{CF}_{2}=\mathrm{CHCl}$ and $8.2 \times 10^{-2}$ moles of $\mathrm{SF}_{5} \mathrm{Br}$ were condensed in a $200 \mathrm{ml}$ Hoke stainless steel vessel at $-196^{\circ}$ and the mixture was heated, in an oven, at $100^{\circ}$ for 14 days. 
The product was distilled and the fraction boiling at $111-111.5^{\circ}$ was collected. The yield for this modified procedure was $73 \%$. The infrared spectrum of this fraction showed the product to be contaminated with the olefin. The procedure used to purify $\mathrm{SF}_{5} \mathrm{CH}_{2} \mathrm{CFClBr}$ did not work in this case. A pure sample was obtained via gas chromatography.

Reaction of $\mathrm{SF}_{5} \mathrm{Br}$ with $\mathrm{CH}_{3} \mathrm{C} \equiv \mathrm{CH}$

In a 3-liter Pyrex glass vessel, $6.25 \times 10^{-2}$ moles of $\mathrm{CH}_{3} \mathrm{C} \equiv \mathrm{CH}$ and $5.6 \times 10^{-3}$ moles of $\mathrm{SF}_{5} \mathrm{Br}$ were condensed at $-196^{\circ}$. Upon warming to room temperature a clear colorless liquid as well as some dark residue were observed. The reaction was complete after standing overnight. The clear liquid was distilled through a Kontes all glass distillation apparatus and the fraction boiling at $111-111.5^{\circ}$ was collected. The dark residue dissolved in acetone but not water and could not be analyzed. The yield for this reaction was $30 \%$.

\section{Reaction of $\mathrm{SF}_{5} \mathrm{Br}$ with $\mathrm{CF}_{3} \mathrm{C} \equiv \mathrm{CH}$}

This reaction was first tried in a 1-liter Pyrex glass vessel in which $2.14 \times 10^{-3}$ moles of $\mathrm{CF}_{3} \mathrm{C} \equiv \mathrm{CH}$ and $2.07 \times 10^{-3}$ moles of $\mathrm{SF}_{5} \mathrm{Br}$ were condensed at $-196^{\circ}$. The yield after 20 days at room temperature was 43\%. A modified method in which $5.3 \times 10^{-2}$ moles of $\mathrm{CF}_{3} \mathrm{C}=\mathrm{CH}$ and $6.1 \times 10^{-2}$ moles of $\mathrm{SF}_{5} \mathrm{Br}$ were condensed in a $200 \mathrm{ml}$ Hoke stainless steel vessel at $-196^{\circ}$. The reactants were heated in an oven at $100^{\circ}$ for four days. The mixture was then distilled. The product, a colorless liquid, boiled at $93 \pm 1^{\circ}$. The yield for this method was $58 \%$.

\section{Gas Chromatography}

The products were analyzed with an Auto-prep gas chromatograph as 
described under physical methods. For the olefins, the column temperature was $59 \pm 1^{\circ}$ and the helium flow rate was $3 \mathrm{ml} / \mathrm{sec}$. Table $\mathrm{X}$ lists the times of appearance of the various compounds. $\mathrm{CCl}_{4}, \mathrm{SF}_{5} \mathrm{CH}=$ $\mathrm{CH}_{2}$ are also shown for comparison. The presence of two peaks in $\mathrm{SF}_{5} \mathrm{CH}=$ $\mathrm{C}\left(\mathrm{CF}_{3}\right) \mathrm{Br}$ indicated the existence of entegegen and zusammen isomers. For a11 other products only one substance was present. For the saturated adducts, the column temperature was $118^{\circ}$ and the helium flow rate was $3 \mathrm{ml} / \mathrm{sec}$.

\section{Chemical Analysis}

The compounds were analyzed by Beller Microanalytical Laboratory (See physical methods) for $\mathrm{C}, \mathrm{H}, \mathrm{S}, \mathrm{C} 1, \mathrm{Br}$ and $\mathrm{F}$. The results are shown in Table XI. There was good agreement with calculated compositions except for the $\mathrm{CF}_{2}=\mathrm{CHCl}$ adduct. The authors are at a loss to explain the discrepancies for the fluorine and bromine analyses in 1ight of the good agreement found for $\mathrm{C}, \mathrm{H}, \mathrm{S}$, and $\mathrm{Cl}$.

\section{Physical Properties}

The physical properties of the adducts are summarized in Table XII. The molecular weights were found using a calibrated bulb and compared very well with the expected values. From Table XII it can be seen that boiling point is lower for the 1, 1-difluoro olefin adduct than the monofluoro adduct. Trifluoromethylacetylyne has a lower boiling point than the methyl-analogy. This can be explained by the importance of intermolecular hydrogen-bonding in partially fluorinated compounds. 
TABLE X

GAS CHROMATOGRAPHY DATA FOR $\mathrm{SF}_{5} \mathrm{Br}$ ADDUCTS

Compound

$\mathrm{CCl}_{4}$

$\mathrm{SF}_{5} \mathrm{CH}=\mathrm{CH}_{2}$

$\mathrm{SF}_{5} \mathrm{CH}=\mathrm{C}\left(\mathrm{CH}_{3}\right) \mathrm{Br}$

$\mathrm{SF}_{5} \mathrm{CH}=\mathrm{C}\left(\mathrm{CF}_{3}\right) \mathrm{Br}$ 1st G.C. isomer

\section{Time (Min.)}

7.3

2.8

12

3.7

6.5

$\mathrm{CCl}_{4}$

2.17

$\mathrm{SF}_{5} \mathrm{CH}_{2} \mathrm{CFClBr}$

4.33

$\mathrm{SF}_{5} \mathrm{CF}_{2} \mathrm{CHClBr}$

3.17

TABLE XI

ELEMENTAL ANALYSES FOR $\mathrm{SF}_{5} \mathrm{Br}$ ADDUCTS

ADDUCTS

$\frac{\mathrm{C}}{\mathrm{wt} . \%}$ Expt'1/Calc.

$\mathrm{SF}_{5} \mathrm{CH}_{2} \mathrm{CFClBr}$

$8.51 / 8.35$

$8.10 / 7.86$

$15.37 / 14.58$

$1.70 / 1.62$

$0.40 / 0.33$

$11.79 / 11.96$

$\frac{\mathrm{H}}{\mathrm{wt} . \%}$

Expt'1/Calc. Expt'1/Calc.

$0.72 / 0.70$

$11.03 / 11.15$

$\mathrm{SF}_{5} \mathrm{CF}_{2} \mathrm{CHClBr}$

$\mathrm{SF}_{5} \mathrm{CH}=\mathrm{C}\left(\mathrm{CH}_{3}\right) \mathrm{Br}$

$\mathrm{SF}_{5} \mathrm{CH}=\mathrm{C}\left(\mathrm{CF}_{3}\right) \mathrm{Br}$

$9.35 / 10.50$

$12.40 / 12.98$

$10.74 / 10.65$ 
TABLE XI (cont'd)

ADDUCTS

$$
\begin{array}{lll}
\frac{\mathrm{F}}{\text { wt.\% }} & \frac{\mathrm{C} 1}{\mathrm{wt. \%}} & \frac{\mathrm{Br}}{\mathrm{wt} . \%} \\
\text { Expt'1/Calc. } & \text { Expt'1/Calc. } & \text { Expt'1/Calc. }
\end{array}
$$

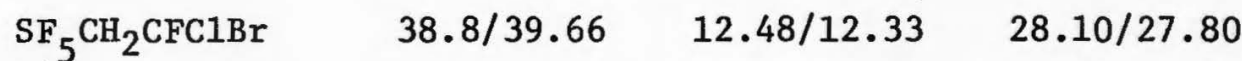

$\mathrm{SF}_{5} \mathrm{CF}_{2} \mathrm{CHClBr} \quad 39.5 / 43.55 \quad 10.68 / 11.61 \quad 32.16 / 26.15$

$\begin{array}{llll}\mathrm{SF}_{5} \mathrm{CH}=\mathrm{C}\left(\mathrm{CH}_{3}\right) \mathrm{Br} & 36.5 / 38.47 & 0 & 34.18 / 32.35\end{array}$

$\begin{array}{llll}\mathrm{SF}_{5} \mathrm{CH}=\mathrm{C}\left(\mathrm{CF}_{3}\right) \mathrm{Br} & 50.2 / 50.51 & 0 & 26.71 / 26.55\end{array}$

TABLE XII

PHYSICAL PROPERTIES OF THE ADDUCTS

Compound

$\mathrm{SF}_{5} \mathrm{CH}_{2} \mathrm{CFClBr}$

$\mathrm{SF}_{5} \mathrm{CF}_{2} \mathrm{CHC} 1 \mathrm{Br}$

$\mathrm{SF}_{5} \mathrm{CH}=\mathrm{C}\left(\mathrm{CH}_{3}\right) \mathrm{Br}$

$\mathrm{SF}_{5} \mathrm{CH}=\mathrm{C}\left(\mathrm{CF}_{3}\right) \mathrm{Br}$
B.P. ( $\left.{ }^{\circ} \mathrm{C}\right) \quad$ Mol. Wt. (Expt'1/Calc.)

119

$285.6 / 287$

$111-111.5$

$296.5 / 305$

$111-111.5$

$245.3 / 247$

$93-94^{\circ} \mathrm{C}$

$301.8 / 301$ 
Infrared Spectra

The infrared spectra for the saturater adducts are listed in Table XIII. The common feature of all the compounds studied is the presence of the $\mathrm{SF}_{5}$ group and its observed infrared absorption bands centered on or about $870 \mathrm{~cm}^{-1}$ which can be directly related to vibrational modes within this group. Cross and co-workers (30) reported that in compounds containing the $\mathrm{SF}_{5}$ group the most intense bands should occur in the region $850-920 \mathrm{~cm}^{-1}$ due to $\mathrm{S}-\mathrm{F}$ stretching modes and in the region of $600 \mathrm{~cm}^{-1}$ due to $\mathrm{S}-\mathrm{F}$ deformation modes. Therefore, the absorption bands at 912,870 , and $845 \mathrm{~cm}^{-1}$ in $\mathrm{SF}_{5} \mathrm{CH}_{2}{ }^{-}$ $\mathrm{CFClBr}$, and for $\mathrm{SF}_{5} \mathrm{CF}_{2} \mathrm{CHClBr}$, at 960,885 and $863 \mathrm{~cm}^{-1}$ are assigned to S-F stretching modes. The S-F deformation modes are located at $600 \mathrm{~cm}^{-1}$ and $596 \mathrm{~cm}^{-1}$ for $\mathrm{SF}_{5} \mathrm{CF}_{2} \mathrm{CHC} 1 \mathrm{Br}$ and $\mathrm{SF}_{5} \mathrm{CH}_{2} \mathrm{CFC1Br}$ respectively. For compounds containing a C-F group, the C-F stretching absorption band is usually located in 1000-1110 $\mathrm{cm}^{-1}$ region while for $\mathrm{CF}_{2}$ groups the region is $1050-1250 \mathrm{~cm}^{-1}$ (31). Therefore, with $\mathrm{SF}_{5} \mathrm{CH}_{2} \mathrm{CFC} 1 \mathrm{Br}$, the absorption band at $1020 \mathrm{~cm}^{-1}$ is probably the C-F absorption band while for $\mathrm{SF}_{5} \mathrm{CF}_{2} \mathrm{CHClBr}$ the $\mathrm{C}-\mathrm{F}$ absorption bands for the $\mathrm{CF}_{2}$ group are found in the 1145-1288 region (31). The absorption bands at $3020 \mathrm{~cm}^{-1}$ and $3040 \mathrm{~cm}^{-1}$ for $\mathrm{SF}_{5} \mathrm{CF}_{2} \mathrm{CHC} 1 \mathrm{Br}$ and $\mathrm{SF}_{5} \mathrm{CH}_{2} \mathrm{CFClBr}$ are assigned to $\mathrm{C}-\mathrm{H}$ stretching vibrations.

The infrared spectra for the olefin adducts are listed in Table XIV. The presence of the highly electronegative $\mathrm{SF}_{5}$ group on one end of an olefinic bond leads to a high intensity for $\mathrm{C}=\mathrm{C}$ stretching frequency. This occurs with medium intensity at 1615 and $1653 \mathrm{~cm}^{-1}$, respectively, for $\mathrm{SF}_{5} \mathrm{CH}=\mathrm{CHCl}$ and $\mathrm{SF}_{5} \mathrm{CH}=\mathrm{CClCH}_{3}$, but only quite feebly 
TABLE XIII

INFRARED ABSORPTION BANDS FOR SATURATED ADDUCTS

$\mathrm{SF}_{5} \mathrm{CF}_{2} \mathrm{CHClBr}_{\text {(gas) }}$

$\mathrm{cm}^{-1}$

$1288(\mathrm{~m})$

1225 (s)

1189 (m)

1163 (s)

1145 (s)

1032 (w)

960 (m)

885 (vs)

$863^{\prime}$ (vs)

$815(\mathrm{~m})$

792. (w)

778 (w)

$731(\mathrm{~s})$

$702(w)$

660 (s)

600 (s)

588 (m-with sh. at 588 and 573)

$\underline{\mathrm{SF}}_{5} \mathrm{CH}_{2} \mathrm{CFClBr}_{\text {(gas) }}$

$\mathrm{cm}^{-1}$

$$
\begin{aligned}
& 1410 \text { (w) } \\
& 1149 \text { (m-s) } \\
& 1020 \text { (s) } \\
& 974 \text { (w) } \\
& 912 \text { (vs) } \\
& 870 \text { (vs) } \\
& 845 \text { (vs) } \\
& 790 \text { (w) } \\
& 720 \text { (w) } \\
& 664 \text { (w) } \\
& 618 \text { (vw) } \\
& 596 \text { (s) } \\
& 568 \text { (m) }
\end{aligned}
$$

$\mathrm{SF}_{5} \mathrm{CF}_{2} \mathrm{CHC1Br}$ (liquid

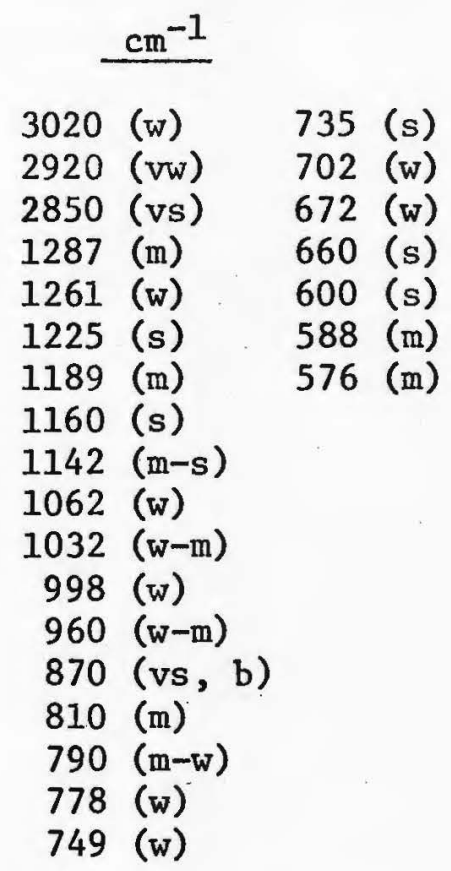

$\mathrm{SF}_{5} \mathrm{CH}_{2} \mathrm{CFClBr}$ (1iquid)

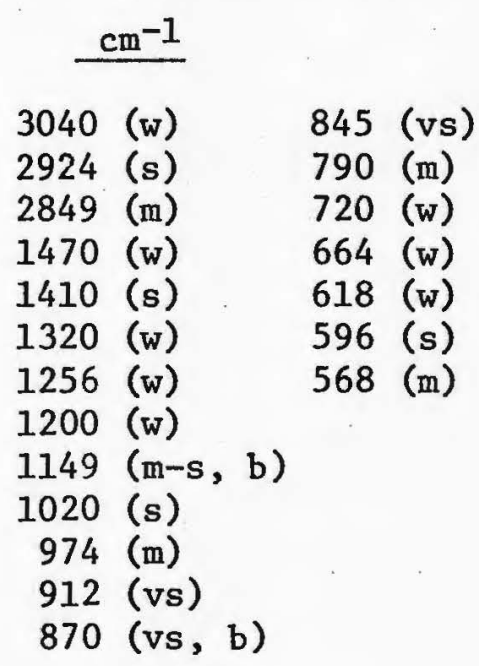


INFRARED ABSORPTION BANDS FOR UNSATURATED ADDUCTS

$\mathrm{SF}_{5} \mathrm{CH}=\mathrm{C}\left(\mathrm{CH}_{3}\right) \mathrm{Br}$ (gas)

$\stackrel{\mathrm{cm}^{-1}}{ }$
3100 (vw)
1643 (m)
1435 (w-m)
1383 (m)
1296 (w)
1084 (m)
980 (s)
863 (s)
883 (s)
735 (m)
619 (m)
598 (s, with sh. at 575)

$\mathrm{SF}_{5} \mathrm{CH}=\mathrm{C}\left(\mathrm{CH}_{3}\right) \mathrm{Br}$ (1iquid)

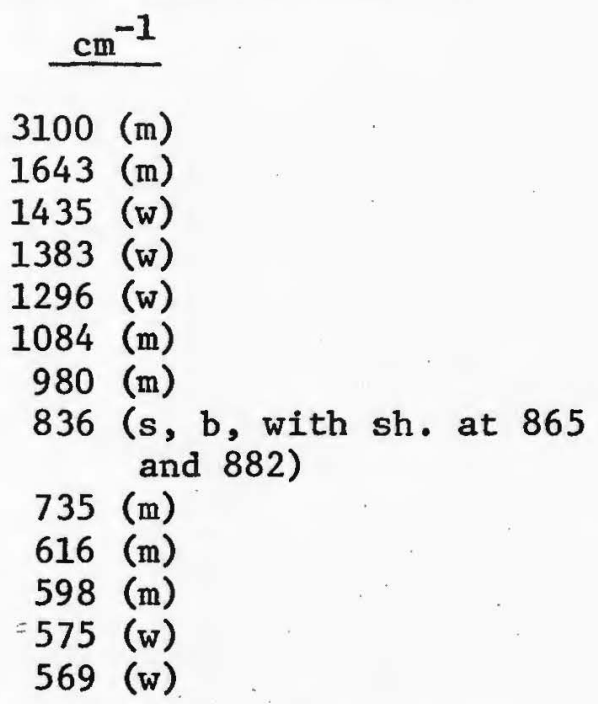

$\underline{\mathrm{SF}}_{5} \mathrm{CH}=\mathrm{C}\left(\mathrm{CF}_{3}\right) \mathrm{Br}$ (gas)

$\mathrm{SF}_{5} \mathrm{CH}=\mathrm{C}\left(\mathrm{CF}_{3}\right) \mathrm{Br}$ (gas) $\quad \mathrm{SF}_{5} \mathrm{CH}^{\mathrm{CH}} \mathrm{C}\left(\mathrm{CF}_{3}\right) \mathrm{Br}$ (gas)

\begin{tabular}{|c|c|c|}
\hline Mixture $-\mathrm{cm}^{-1}$ & $\frac{\text { First - G.C. Isomer - }}{\underline{\mathrm{cm}^{-1}}}$ & $\frac{\text { Sec. G. C. Isomers }}{\underline{\mathrm{cm}^{-1}}}$ \\
\hline $100(\mathrm{~m})$ & $3100(\mathrm{~m})$ & 3100 (w) \\
\hline 630 (m, with sh. & $1637(\mathrm{~m})$ & $1630(\mathrm{~m})$ \\
\hline at 1637) & $1285(\mathrm{w}-\mathrm{m})$ & $1336(\mathrm{~s})$ \\
\hline $1336(\mathrm{~m})$ & 1262 (vs, b) & 1285 (w) \\
\hline 1285 (w) & 1191 (vs, b) & $1262(\mathrm{~m})$ \\
\hline 1262 (vs) & 1120 (w) & $1226(\mathrm{~s})$ \\
\hline & 960 (vs with sh. & 1191 (vs, b) \\
\hline 191 (vs, b) & at 982 ) & 1120 (w) \\
\hline 1120 (w) & 882 (vs, b-with & 944 (vs) \\
\hline 960 (vs) & sh. at 832 ) & 882 (vs, b) \\
\hline 944 (vs) & $765(m-s)$ & 832 (w) \\
\hline 882 (vs, b) & $635(m-s)$ & $770(m-w)$ \\
\hline 832 (w) & $604(\mathrm{~m}-\mathrm{s})$ & 724 (m) \\
\hline 768 (m) & 572 (w) & $654(\mathrm{~m})$ \\
\hline $724(\mathrm{~m}-\mathrm{w})$ & 534 (w) & $604(\mathrm{~m}-\mathrm{s})$ \\
\hline $654(\mathrm{~m})$ & & 572 (พ) \\
\hline $635(\mathrm{~m})$ & & 534 (w) \\
\hline $\begin{array}{l}04(m-s) \\
72(w)\end{array}$ & & \\
\hline (w) & & \\
\hline
\end{tabular}


for the olefins $\mathrm{SF}_{5} \mathrm{CH}=\mathrm{CHCH}_{3}\left(1663 \mathrm{~cm}^{-1}\right), \mathrm{SF}_{5} \mathrm{CH}=\mathrm{CH}_{2}$, and $\mathrm{SF}_{5} \mathrm{CH}_{2} \mathrm{CH}=\mathrm{CH}_{2}$ (30). $\mathrm{SF}_{5} \mathrm{CF}=\mathrm{CF}_{2}$ exhibits an absorption band at $1782 \mathrm{~cm}^{-1}$ which is typical of the values obtained for other fluoroolefins (32). For $\mathrm{SF}_{5}-$ $\mathrm{CH}=\mathrm{C}\left(\mathrm{CH}_{3}\right) \mathrm{Br}$ the $\mathrm{C}=\mathrm{C}$ stretching frequency occurs at $1643 \mathrm{~cm}^{-1}$. The $\mathrm{SF}_{5} \mathrm{CH}=\mathrm{C}\left(\mathrm{CF}_{3}\right) \mathrm{Br}$ compound is a mixture of two isomers (zusammen and entegegen forms). The $\mathrm{C}=\mathrm{C}$ stretching frequency for one isomer (first gas chromatographic isomer) is located at $1637 \mathrm{~cm}^{-1}$ and for the other isomer (second gas chromatographic isomer) is located at $1630 \mathrm{~cm}^{-1}$. The absorption bands at 980 and $870 \mathrm{~cm}^{-1}$ for $\mathrm{SF}_{5} \mathrm{CH}=\mathrm{C}\left(\mathrm{CH}_{3}\right) \mathrm{Br}$ and 960 and $882 \mathrm{~cm}^{-1}$ for $\mathrm{SF}_{5} \mathrm{CH}=\mathrm{C}\left(\mathrm{CF}_{3}\right) \mathrm{Br}$ (first $\mathrm{g}$. c. isomer) and 944 and 882 $\mathrm{cm}^{-1}$ for $\mathrm{SF}_{5} \mathrm{CH}=\mathrm{C}\left(\mathrm{CF}_{3}\right) \mathrm{Br}$ (second $\mathrm{g} \cdot \mathrm{c}$. isomer) represent the $\mathrm{S}-\mathrm{F}$ stretching frequency for these compounds. The S-F deformation modes are located $598 \mathrm{~cm}^{-1}$ and $604 \mathrm{~cm}^{-1}$ for $\mathrm{SF}_{5} \mathrm{CH}=\mathrm{C}\left(\mathrm{CH}_{3}\right) \mathrm{Br}$ and $\mathrm{SF}_{5} \mathrm{CH}=\mathrm{C}\left(\mathrm{CF}_{3}\right) \mathrm{Br}$ respectively.

The absorption band at $3100 \mathrm{~cm}^{-1}$ for $\mathrm{SF}_{5} \mathrm{CH}=\mathrm{C}\left(\mathrm{CF}_{3}\right) \mathrm{Br}$ and $\mathrm{SF}_{5} \mathrm{CH}=\mathrm{C}-$ $\left(\mathrm{CH}_{3}\right) \mathrm{Br}$ is assigned to the $\mathrm{C}-\mathrm{H}$ stretching. In $\mathrm{SF}{ }_{5} \mathrm{CH}=\mathrm{C}\left(\mathrm{CH}_{3}\right) \mathrm{Br}$ the symmetric and asymmetric bending vibration for the $\mathrm{CH}_{3}$ group are tentatively assigned to the 1383 and $1435 \mathrm{~cm}^{-1}$ absorption bands.

\section{Mass Spectra}

The major mass spectra peaks for these adducts are listed in Tables XV to XXI and for the purpose of comparison the spectra for $\mathrm{SF}_{5} \mathrm{CH}=\mathrm{CH}_{2}$ is also shown (Table XXI). A comparison of the major peaks shows that all of the spectra have strong peaks at $\mathrm{m} / \mathrm{e}=89$, the $\mathrm{SF}_{3}{ }^{+}$ peak, and $\mathrm{m} / \mathrm{e}=51$, the $\mathrm{SF}^{+}$peak. In $\mathrm{SF}_{5} \mathrm{CH}=\mathrm{C}\left(\mathrm{CF}_{3}\right) \mathrm{Br}$, the $\mathrm{CF}_{3}{ }^{+}$peak $(\mathrm{m} / \mathrm{e}=69)$ is the most intense one. The compounds, $\mathrm{SF}_{5} \mathrm{CF}_{2} \mathrm{CHClBr}$, $\mathrm{SF}_{5} \mathrm{CH}=\mathrm{C}\left(\mathrm{CF}_{3}\right) \mathrm{Br}, \mathrm{SF}_{5} \mathrm{CH}=\mathrm{CH}_{2}$ had good parent peaks, while $\mathrm{SF}{ }_{5} \mathrm{CH}=\mathrm{C}\left(\mathrm{CH}_{3}\right) \mathrm{Br}$ 
TABLE XV

MASS SPECTRA FOR $\mathrm{SF}_{5} \mathrm{CH}_{2} \mathrm{CFC1Br}$

M/e Rel. Int. Type

26

28

31

44

45

49

51

60

61

62

63

$64 \quad 13.3$

67

69

70

79

$\begin{array}{ll}80 & 56.7\end{array}$

$81 \quad 10.3$

$82 \quad 18.9$

$89 \quad 100$

91

6.7

98

6.7

$\mathrm{C}_{2} \mathrm{H}_{2}^{+}$

$\mathrm{CF}^{+}$

$\mathrm{CCl}^{+}$

$\mathrm{SFCH}^{+}$
$\mathrm{N}_{2}^{+}, \mathrm{CO}^{+}$

$\mathrm{CO}_{2}^{+}, \mathrm{Cs}^{+}$

$\mathrm{C}_{2} \mathrm{H}_{2} \mathrm{~F}^{+}$

$\mathrm{SF}^{+} \mathrm{CCl}^{+}$

$\mathrm{C}_{2} \mathrm{HCl}^{+}$

$\mathrm{C}_{2} \mathrm{H}_{2} \mathrm{Cl}^{+}$

$\mathrm{C}_{2} \mathrm{HCl}^{+}$

127

$\mathrm{SFC}^{+}, \mathrm{C}_{2} \mathrm{H}_{2} \mathrm{Cl}^{+} \quad 129$

138

$\mathrm{CF}_{3}{ }^{+}, \mathrm{SCl}^{+}$

140

141

142

143

144

146

148

158

160

162
Rel.Int. Type

83.3 $\mathrm{CH}_{2} \mathrm{FCFCl}^{+}$

$13.3 \mathrm{BrF}^{+}$

43.3

$\mathrm{SF}_{3} \mathrm{C}^{+}, \mathrm{CH}_{2} \mathrm{FCFCl}^{+}$

$6.7 \mathrm{BrF}_{2}^{+}$

$6.7 \mathrm{BrF}_{2}^{+}$

13.3 $\mathrm{SCBr}^{+}$

$10.0 \quad \mathrm{SCHBr}^{+}$

$13.3 \mathrm{SCBr}^{+}$

$10.0 \mathrm{SCHBr}+$

$50 \quad \mathrm{SF}_{5}{ }^{+}$

$3.3 \quad \mathrm{SF}_{2} \mathrm{C}_{2} \mathrm{Cl}^{+}$

$16.7 \quad \mathrm{SC}_{2} \mathrm{HBr}^{+}$

$23.3 \mathrm{SF}_{5} \mathrm{CH}^{+}, \mathrm{SC}_{2} \mathrm{HBr}^{+}$

$3.3 \mathrm{SC}_{2} \mathrm{H}_{2} \mathrm{Br}^{+}$

$30.0 \quad \mathrm{SFCBr}^{+}$

$3.3 \mathrm{SC}_{2} \mathrm{H}_{2} \mathrm{Br}^{+}$

$30.0 \quad \mathrm{SFCBr}^{+}$

$6.7 \quad \mathrm{SC} 1 \mathrm{Br}^{+}$

$2.2 \mathrm{SClBr}^{+}$

$40 \quad \mathrm{SF}_{5} \mathrm{CF}^{+}$

$55 \quad \mathrm{SF}_{5} \mathrm{CH}_{2} \mathrm{~F}^{+}$

$13.3 \mathrm{SCHC}_{\mathrm{Brr}}{ }^{+}$ 
TABLE XV (con't)

M/e Rel. Int. Type

175

177
3.3

3.3
$\mathrm{SF}_{2} \mathrm{CH}_{2} \mathrm{CBr}^{+}$

$\mathrm{SF}_{2} \mathrm{CH}_{2} \mathrm{CBr}^{+}$

M/e Rel. Int. Type

207

35

$\mathrm{SF}_{5} \mathrm{CH}_{2} \mathrm{CFCl}^{+}$

209

11.7

$\mathrm{SF}_{5} \mathrm{CH}_{2} \mathrm{CFCl}^{+}$

TABLE XVI

MASS SPECTRA FOR $\mathrm{SF}_{5} \mathrm{CF}_{2} \mathrm{CHC1Br}$

M/e Re1. Int. Type

25

28

29

32

36

38

44

47

48

49

50

51

62

63

64

66

1.1

$\mathrm{C}_{2} \mathrm{H}^{+}$

1.1

4.1

17.4

17.4

5.8

15.2

15.2

34.8

6.5

$\mathrm{COH}^{+}$

$\mathrm{HCl}^{+}$

$\mathrm{HCl}^{+}$

$\mathrm{CCl}^{+}$

$\mathrm{CC1}^{+}$

$\mathrm{SF}^{+}$

$\mathrm{SCF}^{+}$
$\mathrm{N}_{2}^{+}, \mathrm{CO}^{+}$

$\mathrm{s}^{+}, \mathrm{O}_{2}^{+}$

$\mathrm{CO}_{2}^{+}, \mathrm{CS}^{+}$

$\mathrm{CHC1}^{+}$

$\mathrm{CHCl}^{+}$

$\mathrm{C}_{2} \mathrm{HCl}^{+}$

$\mathrm{SFCH}^{+}$

$\mathrm{CFCl}^{+}$
100

M/e Rel. Int. Type

67

69

70

78

79

80

81

82

85

86

89

98

99

101

105

43.5. $\mathrm{SCl}^{+}$

$8.6 \mathrm{SF}_{2}^{+}$

.3.8 $\mathrm{HBr}^{+}$

$3.8 \mathrm{HBr}^{+}$

$39.1 \mathrm{SF}_{3}{ }^{+}$
$17.3 \mathrm{CF}_{3}{ }^{+}, \mathrm{SC}^{+}$

$4.3 \quad \mathrm{C}_{2} \mathrm{FCl}^{+}$

$21.7 \quad \mathrm{CHCFCl}^{+}, \mathrm{Br}^{+}$

7.4 $\mathrm{CHCFCl}^{+}, \mathrm{Br}^{+}$

$21.7 \quad \mathrm{CF}_{2} \mathrm{Cl}^{+}$

$19.6 . \mathrm{HCF}_{2} \mathrm{Cl}^{+}$

$100 \mathrm{CF}_{2} \mathrm{CHCl}^{+}, \mathrm{BrF}^{+}, \mathrm{SFCCl}^{+}$

$15.2 \mathrm{SFCHCl}^{+}$

$82.5 \mathrm{CF}_{2} \mathrm{CHCl}^{+}, \mathrm{SFCCl}^{+}, \mathrm{BrF}^{+}$

4.9. $\mathrm{SFCHCl}^{+}$

$4.9 \quad \mathrm{SClF}_{2}^{+}$ 
TABLE XVI (con't)

M/e Re1. Int. Type

$111 \quad 4.5 \quad \mathrm{SBr}^{+}$

113

$$
4.5 \quad \mathrm{SBr}^{+}
$$

$117 \quad 93.7 \quad \mathrm{SF}_{2} \mathrm{CHCl}^{+}$

$118 \quad 17.4 \quad \mathrm{SF}_{2} \mathrm{CHCl}^{+}$

$119 \quad 31.1 \quad \mathrm{SF}_{2} \mathrm{CCl}^{+}$

$120 \quad 5.7 \quad \mathrm{SF}_{2} \mathrm{CHC1}^{+}$

$127 \quad 82.6 \quad \mathrm{SF}_{5}{ }^{+}$

$129 \quad 39.1 \quad \mathrm{SF}_{2} \mathrm{C}_{2} \mathrm{C}^{+}$

$131 \quad 13.1 \quad \mathrm{SF}_{2} \mathrm{C}_{2} \mathrm{Cl}+$

$1424.3 \quad \mathrm{SFCBr}^{+}$

$144 \quad 4.3 \quad \mathrm{SFCBr}^{+}$

$177 \quad 39.1 \quad \mathrm{CHCF}_{2} \mathrm{Cl}^{35} 5_{\mathrm{Br}} 79+$

$179 \quad 55.6 \quad \mathrm{CHCF}_{2} \mathrm{Cl}^{35} 5_{\mathrm{Br}} 81+$ $\mathrm{CHCF}_{2} \mathrm{Cl}^{37} \mathrm{Br}^{79+}$

$181 \quad 14.5 \quad \mathrm{CHCF}_{2} \mathrm{Cl}^{37} \mathrm{Br}^{81+}$
M/e Rel. Int. Type

$196 \quad 39.1 \quad \mathrm{SFHCl}^{35} \mathrm{CF}_{2} \mathrm{Br}^{79+}$

$19856.1 \quad \mathrm{CFHCl}^{35} \mathrm{CF}_{2} \mathrm{Br}^{81+}$

$\mathrm{CFHCl}^{37} \mathrm{CF}_{2} \mathrm{Br}^{79+}$

$200 \quad 11.8$

$\mathrm{CFHCl}^{37} \mathrm{CF}_{2} \mathrm{Br}^{81+}$

$304 \quad 3.2$

$\mathrm{SF}_{5} \mathrm{CHCl}^{35} \mathrm{CF}_{2} \mathrm{Br} 79+$

$306 \quad 6.5$

$\mathrm{SF}_{5} \mathrm{CHCl}^{35} \mathrm{CF}_{2} \mathrm{Br}^{81+}$

$\mathrm{SF}_{5} \mathrm{CHCl}^{37} \mathrm{CF}_{2} \mathrm{Br}^{79+}$

$308 \quad 1.0$

$\mathrm{SF}_{5} \mathrm{CHCl}^{37} \mathrm{CF}_{2} \mathrm{Br}^{81+}$ 
TABLE XVII

MASS SPECTRA FOR $\mathrm{SF}_{5} \mathrm{CH}=\mathrm{C}\left(\mathrm{CH}_{3}\right) \mathrm{Br}$

\begin{tabular}{|c|c|c|}
\hline M/e & Re1. Int. & Type \\
\hline 28 & 18.8 & $\mathrm{C}_{2} \mathrm{H}_{4}^{+}$ \\
\hline 31 & 3.1 & $\mathrm{CF}^{+}$ \\
\hline 32 & 3.1 & $\mathrm{CHF}^{+}$ \\
\hline 33 & 12.5 & $\mathrm{CH}_{2} \mathrm{~F}^{+}$ \\
\hline 37 & 12.5 & $\mathrm{C}_{3} \mathrm{H}^{+}$ \\
\hline 38 & 18.8 & $\mathrm{C}_{3} \mathrm{H}_{2}^{+}$ \\
\hline 39 & 100 & $\mathrm{C}_{3} \mathrm{H}_{3}^{+}$ \\
\hline 51 & 3.1 & $\mathrm{SF}^{+}$ \\
\hline 40 & 12.5 & $\mathrm{C}_{3} \mathrm{H}_{4}^{+}$ \\
\hline 57 & 6.3 & $\mathrm{C}_{2} \mathrm{HS}^{+}$ \\
\hline 59 & 18.8 & $\mathrm{C}_{3} \mathrm{H}_{4} \mathrm{~F}^{+}$ \\
\hline 69 & 12.5 & $\mathrm{CF}_{3}{ }^{+}$ \\
\hline 71 & 6.3 & $\mathrm{SF}_{2} \mathrm{H}^{+}$ \\
\hline 89 & 50 & $\mathrm{SF}_{3}{ }^{+}$ \\
\hline 93 & 6.3 & $\mathrm{C}_{2} \mathrm{H}_{3} \mathrm{Br}^{+}$ \\
\hline 95 & 6.3 & $\mathrm{C}_{2} \mathrm{H}_{3} \mathrm{Br}^{+}$ \\
\hline 119 & 18.8 & $\mathrm{C}_{3} \mathrm{H}_{4} \mathrm{Br}^{+}$ \\
\hline 121 & 18.8 & $\mathrm{C}_{3} \mathrm{H}_{4} \mathrm{Br}+$ \\
\hline 127 & 18.8 & $\mathrm{SF}_{5}{ }^{+}$ \\
\hline 137 & 18.8 & $\mathrm{C}_{3} \mathrm{H}_{3} \mathrm{BrF}^{+}$ \\
\hline 139 & 18.8 & $\mathrm{C}_{3} \mathrm{H}_{3} \mathrm{BrF}^{+}$ \\
\hline 167 & 25 & $\mathrm{SF}_{5} \mathrm{C}_{3} \mathrm{H}_{4}^{+}$ \\
\hline
\end{tabular}

There are also minor peaks for masses $18\left(\mathrm{H}_{2} \mathrm{O}^{+}\right), 44\left(\mathrm{CO}_{2}^{+}\right), 65\left(\mathrm{CH}_{2} \mathrm{CHF}_{2}{ }^{+}\right)$. 
TABLE XVIII

MASS SPECTRA FOR $\mathrm{SF}_{5} \mathrm{CH}=\mathrm{C}\left(\mathrm{CF}_{3}\right) \mathrm{Br}$

M/e Rel. Int. Type M/e Rel. Int. Type

25

3.0

$\mathrm{C}_{2} \mathrm{H}_{1}^{+}$

106

4.6

$\mathrm{C}_{2} \mathrm{HBr}^{+}, \mathrm{SF}_{2} \mathrm{C}_{3}{ }^{+}$

28

15.2

$\mathrm{N}_{2}^{+}, \mathrm{CO}^{+}$

108

1.5

$\mathrm{SF}_{4}^{+}$

31

12.1

$\mathrm{CF}^{+}$

113

27.3

$\mathrm{SF}_{3} \mathrm{C}_{2}{ }^{+}$

32

3.0

$\mathrm{s}^{+}, \mathrm{O}_{2}{ }^{+}$

123

$3.0 \mathrm{SCBr}^{+}$

44

3.0

$\mathrm{CO}_{2}{ }^{+}$

125

$3.0 \mathrm{SCBr}^{+}$

50

3.0

$\mathrm{CF}_{2}{ }^{+}$

127

30.3

$\mathrm{SF}_{5}+$

51

25

$\mathrm{SF}^{+}$

129

$6.1 ?$

55

3.0

$\mathrm{C}_{3} \mathrm{~F}^{+}$

131

4.6

$\mathrm{C}_{2} \mathrm{~F}_{2} \mathrm{CF}_{3}{ }^{+}$

56

4.6

$\mathrm{C}_{3} \mathrm{HF}^{+}$

142

4.6

$\mathrm{C}_{2} \mathrm{~F}_{2} \mathrm{HBr}^{+}$

57

3.0

$\mathrm{C}_{2} \mathrm{HS}^{+}$

144

4.6

$\mathrm{C}_{2} \mathrm{~F}_{2} \mathrm{HBr}^{+}$

69

100

$\mathrm{CF}_{3}{ }^{+}$

153

3.0

$\mathrm{C}_{3} \mathrm{~F}_{2} \mathrm{Br}^{+}$

70

13.6

$\mathrm{SF}_{2}{ }^{+}$

155

3.0

$\mathrm{C}_{3} \mathrm{~F}_{2} \mathrm{Br}^{+}$

74

3.0

$\mathrm{C}_{2} \mathrm{CF}_{2}{ }^{+}$

173

48.5

$\mathrm{CHCCF}_{3} \mathrm{Br}+$

75

30.3

$\mathrm{CHCCF}_{2}{ }^{+}$

175

48.5

$\mathrm{CHCF}_{3} \mathrm{Br}^{+}$

79

3.0

$\mathrm{Br}^{+}$

191

3.0

$\mathrm{CFCCF}_{3} \mathrm{Br}^{+}$

81

3.0

$\mathrm{Br}^{+}, \mathrm{CCF}_{3}^{+} 192$

28.8

$\mathrm{CHFCCF}_{3} \mathrm{Br}^{+}$

85

6.1

?

193

3.0

$\mathrm{CFCCF}_{3} \mathrm{Br}^{+}$

89

51.5

$\mathrm{SF}_{3}{ }^{+}$

194

28.8

$\mathrm{CHFCCF}_{3} \mathrm{Br}^{+}$

93

9.1

$\mathrm{C}_{2} \mathrm{CF}_{3}{ }^{+}$

221

3.0

$\mathrm{SF}_{5} \mathrm{CHCCF}_{3}+$

94

9.1

$\mathrm{C}_{2} \mathrm{HCF}_{3}{ }^{+} \quad 281$

7.6

$\mathrm{SF}_{5} \mathrm{C}_{2} \mathrm{HBrCF}_{2}{ }^{+}$

104

4.6

$\mathrm{C}_{2} \mathrm{HBr}^{+}$

283

7.6

$\mathrm{SF}_{5} \mathrm{C}_{2} \mathrm{HBrCF}_{2}{ }^{+}$ 
TABLE XVIII (con't)

M/e Re1. Int. Type

$300 \quad 30.3 \quad \mathrm{SF}_{5} \mathrm{C}_{2} \mathrm{HCF}_{3} \mathrm{Br}^{+}$

$302 \quad 30.3 \quad \mathrm{SF}_{5} \mathrm{C}_{2} \mathrm{HCF}_{3} \mathrm{Br}^{+}$ 
TABLE XIX

MASS SPECTRA FOR $\mathrm{SF}_{5} \mathrm{CH}=\mathrm{C}\left(\mathrm{CF}_{3}\right) \mathrm{Br}$ FIRST G.C. ISOMER

M/e Re1. Int. Type

25

28

31

32

44

50

51

55

56

57

$69 \quad 100$

$\mathrm{C}_{2} \mathrm{H}^{+}$

3.1

7.8

1.6

3.1

3.1

6.3

1.6

6.3

1.6

$70 \quad 15.6$

$\mathrm{N}_{2}^{+}, \mathrm{CO}^{+}$

$\mathrm{CF}^{+}$

$\mathrm{S}^{+}, \mathrm{O}_{2}^{+}$

$\mathrm{CO}_{2}+$

$\mathrm{CF}_{2}{ }^{+}$

$\mathrm{SF}^{+}$

$\mathrm{C}_{3} \mathrm{~F}^{+}$

$\mathrm{C}_{3} \mathrm{HF}^{+}$

$\mathrm{C}_{2} \mathrm{HS}^{+}$

74

3.1

$75 \quad 34.4$

79

6.3

81

6.3

$\mathrm{CF}_{3}{ }^{+}$

$\mathrm{SF}_{2}{ }^{+}$

$\mathrm{C}_{2} \mathrm{CF}_{2}^{+}$

$\mathrm{CHCCF}_{2}{ }^{+}$

$\mathrm{Br}^{+}$

89

91

$93 \quad 10.9$

$\mathrm{Br}^{+}, \mathrm{CCF}_{3}{ }^{+}$

$94 \quad 10.9$

99
$\mathrm{SF}_{3}{ }^{+}$

?

$\mathrm{C}_{3} \mathrm{~F}_{3}{ }^{+}$

46.9

$\mathrm{CHCCF}_{3}{ }^{+}$

?
M/e Re1. Int. Type

104

9.4

$\mathrm{C}_{2} \mathrm{HBr}^{+}$

106

9.4

$\mathrm{C}_{2} \mathrm{HBr}^{+}$

108

1.6

$\mathrm{SF}_{4}{ }^{+}$

113

37.5

$\mathrm{SF}_{3} \mathrm{C}_{2}{ }^{+}$

123

$6.3 \mathrm{SCBr}^{+}$

125

6.3

$\mathrm{SCBr}^{+}$

127

42.2

$\mathrm{SF}_{5}{ }^{+}$

129

6.3

?

131

6.3

$\mathrm{C}_{2} \mathrm{~F}_{2} \mathrm{CF}_{3}{ }^{+}$

142

7.8

$\mathrm{C}_{2} \mathrm{~F}_{2} \mathrm{HBr}^{+}$

144

7.8

$\mathrm{C}_{2} \mathrm{~F}_{2} \mathrm{HBr}^{+}$

153

3.1

$\mathrm{C}_{3} \mathrm{~F}_{2} \mathrm{Br}^{+}$

155

173

175

191

192

193

3.1

$\mathrm{C}_{3} \mathrm{~F}_{2} \mathrm{Br}^{+}$

53.1

$\mathrm{C}_{2} \mathrm{HCF}_{3} \mathrm{Br}^{+}$

53.1

$\mathrm{C}_{2} \mathrm{HCF}_{3} \mathrm{Br}^{+}$

$3.1 \quad \mathrm{CFCCF}_{3} \mathrm{Br}^{+}$ $50.0 \quad \mathrm{CHFCCF}_{3} \mathrm{Br}^{+}$

$3.1 \quad \mathrm{CFCCF}_{3} \mathrm{Br}^{+}$

$19450.0 \quad \mathrm{CHFCCF}_{3} \mathrm{Br}^{+}$

221

$3.1 \mathrm{SF}_{5} \mathrm{CHCCF}_{3}{ }^{+}$

281

$28.1 \quad \mathrm{SF}_{5} \mathrm{C}_{2} \mathrm{HBrCF}_{2}{ }^{+}$ 
TABLE XIX ( $\left.\operatorname{con}^{\top} t\right)$

M/e Rel. Int. Type

$283 \quad 28.1 \quad \mathrm{SF}_{5} \mathrm{C}_{2} \mathrm{HBrCF}_{2}{ }^{+}$

$300 \quad 68.8 \quad \mathrm{SF}_{5} \mathrm{C}_{2} \mathrm{HCF}_{3} \mathrm{Br}^{+}$

$302 \quad 68.8 \quad \mathrm{SF}_{5} \mathrm{C}_{2} \mathrm{HCF}_{3} \mathrm{Br}^{+}$ 
TABLE XX

MASS SPECTRA FOR $\mathrm{SF}_{5} \mathrm{CH}=\mathrm{C}\left(\mathrm{CF}_{3}\right) \mathrm{Br}$ SECOND G. C. ISOMER

\begin{tabular}{|c|c|c|c|c|c|}
\hline $\mathrm{M} / \mathrm{e}$ & Re1. Int. & Type & $\underline{M / e}$ & Re1. Int. & Type \\
\hline 25 & 2.2 & $\mathrm{C}_{2} \mathrm{H}^{+}$ & 104 & 11.1 & $\mathrm{C}_{2} \mathrm{HBr}^{+}$ \\
\hline 28 & 4.1 & $\mathrm{~N}_{2}^{+}, \mathrm{CO}^{+}$ & 106 & 11.1 & $\mathrm{C}_{2} \mathrm{HBr}^{+}$ \\
\hline 31 & 7.8 & $\mathrm{CF}^{+}$ & 108 & 2.2 & $\mathrm{SF}_{4}^{+}$ \\
\hline 32 & 1.1 & $\mathrm{~S}^{+}, \mathrm{O}_{2}^{+}$ & 113 & 24.4 & $\mathrm{SF}_{3} \mathrm{C}_{2}{ }^{+}$ \\
\hline 44 & 4.4 & $\mathrm{CO}_{2}^{+}$ & 123 & 4.1 & $\mathrm{SCBr}+$ \\
\hline 50 & 4.4 & $\mathrm{CF}_{2}{ }^{+}$ & 125 & 4.1 & $\mathrm{sCBr}{ }^{+}$ \\
\hline 51 & 4.4 & $\mathrm{SF}^{+}$ & 127 & 33.3 & $\mathrm{SF}_{5}+$ \\
\hline 55 & 2.2 & $\mathrm{C}_{3} \mathrm{~F}^{+}$ & 129 & 6.7 & $?$ \\
\hline 56 & 4.1 & $\mathrm{C}_{3} \mathrm{HF}^{+}$ & 131 & 6.7 & $\mathrm{C}_{2} \mathrm{~F}_{2} \mathrm{CF}_{3}+$ \\
\hline 57 & 2.2 & $\mathrm{c}_{2} \mathrm{HS}^{+}$ & 142 & 5.6 & $\mathrm{c}_{2} \mathrm{~F}_{2} \mathrm{HBr}^{+}$ \\
\hline 69 & 100 & $\mathrm{CF}_{3}+$ & 144 & 5.6 & $\mathrm{C}_{2} \mathrm{~F}_{2} \mathrm{HBr}^{+}$ \\
\hline 70 & 14.4 & $\mathrm{SF}_{2}{ }^{+}$ & 153 & 4.4 & $\mathrm{C}_{3} \mathrm{~F}_{2} \mathrm{Br}^{+}$ \\
\hline 74 & 4.4 & $\mathrm{C}_{2} \mathrm{CF}_{2}^{+}$ & 155 & 4.4 & $\mathrm{C}_{3} \mathrm{~F}_{2} \mathrm{Br}^{+}$ \\
\hline 75 & 22.2 & $\mathrm{CHCCF}_{2}{ }^{+}$ & 173 & 56.6 & $\mathrm{C}_{2} \mathrm{HCF}_{3} \mathrm{Br}^{+}$ \\
\hline 79 & 4.4 & $\mathrm{Br}^{+}$ & 175 & 56.6 & $\mathrm{C}_{2} \mathrm{HCF}_{3} \mathrm{Br}^{+}$ \\
\hline 81 & 4.4 & $\mathrm{Br}^{+}, \mathrm{CCF}_{3}^{+}$ & 191 & 2.2 & $\mathrm{CFCCF}_{3} \mathrm{Br}^{+}$ \\
\hline 89 & 55.6 & $\mathrm{SF}_{3}{ }^{+}$ & 192 & 56.6 & $\mathrm{CHFCCF}_{3} \mathrm{Br}^{+}$ \\
\hline 91 & 4.1 & $?$ & 193 & 2.2 & $\mathrm{CFCCF}_{3} \mathrm{Br}^{+}$ \\
\hline 93 & $11: 1$ & $\mathrm{C}_{3} \mathrm{~F}_{3}^{+}$ & 194 & 56.6 & $\mathrm{CHFCCF}_{3} \mathrm{Br}^{+}$ \\
\hline 94 & 10.8 & $\mathrm{C}_{3} \mathrm{HF}_{3}{ }^{+}$ & 221 & 4.4 & $\mathrm{SF}_{5} \mathrm{CHCCF}_{3}^{+}$ \\
\hline 99 & 2.0 & $?$ & 281 & 6.7 & $\mathrm{SF}_{5} \mathrm{C}_{2} \mathrm{HBrCF}_{2}+$ \\
\hline
\end{tabular}


TABLE XX (con't)

M/e Rel. Int. Type

283

6.7

$\mathrm{SF}_{5} \mathrm{C}_{2} \mathrm{HBrCF}_{2}{ }^{+}$

300

53.3

$\mathrm{SF}_{5} \mathrm{C}_{2} \mathrm{HCF}_{3} \mathrm{Br}^{+}$

302

53.3

$\mathrm{SF}_{5} \mathrm{C}_{2} \mathrm{HCF}_{3} \mathrm{Br}^{+}$ 
TABLE XXI

MASS SPECTRA PEAKS FOR $\mathrm{SF}_{5} \mathrm{CH}=\mathrm{CH}_{2}$

\begin{tabular}{|c|c|c|}
\hline$\underline{\mathrm{M} / \mathrm{e}}$ & Re1. Int. & Type \\
\hline 26 & 14.5 & $\mathrm{C}_{2} \mathrm{H}_{2}^{+}$ \\
\hline 27 & 100 & $\mathrm{C}_{2} \mathrm{H}_{3}+$ \\
\hline 28 & 5.3 & $\mathrm{~N}_{2}^{+}, \mathrm{CO}^{+}$ \\
\hline 44 & 2.6 & $\mathrm{CO}_{2}^{+}$ \\
\hline 46 & 17.1 & $\mathrm{C}_{2} \mathrm{H}_{3} \mathrm{~F}^{+}$ \\
\hline 51 & 3.9 & $\mathrm{SF}^{+}$ \\
\hline 56 & 1.3 & $\mathrm{C}_{2} \mathrm{~s}^{+}$ \\
\hline 57 & 1.3 & $\mathrm{C}_{2} \mathrm{HS}^{+}$ \\
\hline 58 & 1.3 & $\mathrm{C}_{2} \mathrm{H}_{2} \mathrm{~S}^{+}$ \\
\hline 69 & 1.3 & $\mathrm{CF}_{3}^{+}$(impurity ?) \\
\hline 70 & 9.2 & $\mathrm{SF}_{2}^{+}$ \\
\hline 89 & 100 & $\mathrm{SF}_{3}{ }^{+}$ \\
\hline 91 & 2.6 & $\mathrm{SF}_{3} \mathrm{H}_{2}^{+}$ \\
\hline 108 & 2.6 & $\mathrm{SF}_{4}^{+}$ \\
\hline 109 & 1.3 & $\mathrm{SF}_{4} \mathrm{H}^{+}$ \\
\hline 127 & 7.9 & $\mathrm{SF}_{5}^{+}$ \\
\hline 135 & 9.2 & $\mathrm{SF}_{4} \mathrm{C}_{2} \mathrm{H}_{3}^{+}$ \\
\hline 154 & 2.6 & $\mathrm{SF}_{5} \mathrm{C}_{2} \mathrm{H}_{3}^{+}$ \\
\hline
\end{tabular}

There are also minor peaks for masses $18\left(\mathrm{H}_{2} \mathrm{O}^{+}\right), 20\left(\mathrm{HF}^{+}\right), 97\left(\mathrm{SF}_{2} \mathrm{C}_{2} \mathrm{H}_{3}{ }^{+}\right)$, $113\left(\mathrm{SF}_{3} \mathrm{C}_{2}{ }^{+}\right)$. 
and $\mathrm{SFCH}_{2} \mathrm{CFClBr}$ had no parent peaks. The major peaks for $\mathrm{SF}_{5} \mathrm{CH}=\mathrm{C}\left(\mathrm{CF}_{3}\right)-$ $\mathrm{Br}$ (mixture) and its two isomers are essentially the same. The difference between the peaks of two isomers is the relatively higher tendency for the first $\mathrm{g} \cdot \mathrm{c}$. isomer to lose a fluorine atom as indicated by the relative intensity of peaks at $\mathrm{m} / \mathrm{e}=281$ and $\mathrm{m} / \mathrm{e}=283$ (the $\mathrm{SF}_{5} \mathrm{C}_{2} \mathrm{BrCF}_{2}{ }^{+}$peaks).

It is thought that this loss of fluorine is from the SF5 group rather than from the $\mathrm{CF}_{3}$ group because the $\mathrm{S}-\mathrm{F}$ bond strength is about $76 \mathrm{kcal} / \mathrm{mole}$ while the $\mathrm{C}-\mathrm{F}$ bond strength is $\sim 116 \mathrm{kcal} / \mathrm{mole}$ and because the $\mathrm{CF}_{3}{ }^{+}$molecular ion is much more abundant than the $\mathrm{SF}_{5}{ }^{+}$ion. The mass spectrum of $\mathrm{SF}_{5} \mathrm{C} \equiv \mathrm{CH}(12)$ had peaks at $\mathrm{m} / \mathrm{e}=152$ (parent), 133 $\left(\mathrm{SF}_{4} \mathrm{C}_{2} \mathrm{H}^{+}\right), 127\left(\mathrm{SF}_{5}{ }^{+}\right), 89\left(\mathrm{SF}_{3}{ }^{+}\right)$and $44\left(\mathrm{C}_{2} \mathrm{HF}^{+}\right)$. The presence of the $\mathrm{m} / \mathrm{e}=133$ demonstrates that fluorine loss from the SF 5 group of the parent compound is possible. It is interesting to note however, that the mass spectrum of $\mathrm{SF}_{5} \mathrm{CH}=\mathrm{C}\left(\mathrm{CH}_{3}\right) \mathrm{Br}$ does not show either a parent peak or a peak due to the loss of a fluorine atom.

\section{Nuclear Magnetic Resonance}

The nuclear magnetic resonance data for the adducts are listed in Table XXII. The proton nmr spectrum for $\mathrm{SF}_{5} \mathrm{CH}_{2} \mathrm{CClFBr}$ is a multiplet of 13 lines with a band center of $4.5 \mathrm{ppm}$. The spectrum was not resolved but its complexity and the band center establishes that the $\mathrm{SF}_{5}$ group is attached to the $\mathrm{CH}_{2}$ group. In $\mathrm{SF}_{5} \mathrm{CH}_{2} \mathrm{CHFBr}$ and $\mathrm{SF}_{5} \mathrm{CH}_{2} \mathrm{CF}_{2} \mathrm{Br}$ the band centers are 4.27 and 4.46 respectively (4). For $\mathrm{SF}_{5} \mathrm{CF}_{2} \mathrm{CHClBr}$, the proton nmr spectrum consists of four bands with a band center of $5.9 \mathrm{ppm}$. The four line pattern unambigously demonstrates that the $\mathrm{SF}_{5}$ group is attached to the $\mathrm{CF}_{2}$ group and the $\mathrm{CF}_{2}$ group is attached 
TABLE XXII

NMR DATA

Proposed Structure

Skeletal Atom Number

1

2

3

$\mathrm{SF}_{5} \quad \mathrm{CH}_{2} \quad \mathrm{CFClBr}$

$\mathrm{SF}_{5} \quad \mathrm{CF}_{2} \quad \mathrm{CHC} 1 \mathrm{Br}$

$\mathrm{SF}_{5} \quad \mathrm{CH} \quad \mathrm{C}\left(\mathrm{CF}_{3}\right) \mathrm{Br} * * * \quad 7.60$

$\mathrm{SF}_{5} \quad \mathrm{CH} \quad \mathrm{C}\left(\mathrm{CF}_{3}\right) \mathrm{Br} * * * * 7.13$

$\mathrm{SF}_{5} \quad \mathrm{CH} \quad \mathrm{C}\left(\mathrm{CH}_{3}\right) \mathrm{Br} \quad 6.76$
Coupling Constants

Band Centers *

CH $\quad \begin{array}{lllll}\mathrm{CH}_{2} & \mathrm{CH}_{3} & \mathrm{~J}_{1,1}^{\mathrm{H}, \mathrm{F}} & \mathrm{J}_{3,2}^{\mathrm{H}, \mathrm{F}} & \mathrm{J}_{3,2}^{\mathrm{M}, \mathrm{F}^{\prime}}\end{array}$

$4.5 @$
6.5

8.6

$2.57 \quad 7.8$

*Chemical shifts in parts per million downfield from $\mathrm{Si}\left(\mathrm{CH}_{3}\right)_{4}$ internal standard.

**Measured in cycles per second

***First gass Chromatographic isomer.

$* * * *$ Second gas Chromatographic isomer.

@Band center of multiplet of 13 major lines. 
to the $\mathrm{CH}$ group. The fluorine atoms of the $\mathrm{CF}_{2}$ group are nonequivalent and split the hydrogen into the four line pattern. The coupling constants, $\mathrm{J}_{3}^{\mathrm{H}}, \mathrm{F}$ and $\mathrm{J}_{3}^{\mathrm{H}, \mathrm{F}^{1}}$ and 12.6 and 6.0 cps respectively. For $\mathrm{SF}_{5} \mathrm{CHFCF}_{2} \mathrm{Br}$ the corresponding coupling constants were 13 and 3.0 cps (4). The band center for $\mathrm{SF}_{5} \mathrm{CHFCF}_{2} \mathrm{Br}$ was $5.58 \mathrm{ppm}$ (4). The first $\mathrm{g} \cdot \mathrm{c}$. isomer of $\mathrm{SF}_{5} \mathrm{CH}=\mathrm{C}\left(\mathrm{CF}_{3}\right) \mathrm{Br}$ had a band center of $7.60 \mathrm{ppm}$ while the second $\mathrm{g} . \mathrm{c}$. isomer had a band center of $7.13 \mathrm{ppm}$. The proton spectra for both isomers gave a five line pattern due to splitting of the $\mathrm{SF}_{5}$ group attached to the carbon with the hydrogen. It is interesting to note that the $\mathrm{J}_{1,1}^{\mathrm{H}, F}$ coupling constant for the two isomers are different. The values for these two coupling constants are in line with the values reported for other $\mathrm{SF}_{5}$ olefins (12).

Integration of the areas for the $\mathrm{CH}$ peaks in the starting mixture indicates that the concentration of the two isomers are approximately equal.

In order to differentiate between the entegegen and zusammen isomers present in the starting mixture the relative values for the long range coupling between the $\mathrm{CF}_{3}$ and $\mathrm{H}$ groups were determined. The A-60 nmr instrument was unable to determine the coupling constant expected for the four line pattern and therefore the relative width at half-peak height was used. For the first g.c. isomer. The width at half-peak height was $3.6 \mathrm{cps}$ and for the second g.c. isomer the width was $2.4 \mathrm{cps}$. This analysis definitely proves that the $\mathrm{CF}_{3}-\mathrm{H}$ coupling is much stronger in the first g.c. isomer. W. G. Finnegan and W. P. Norris (33) found that for 
<smiles>ClC([14Cl])=C[13Cl]</smiles>

and<smiles>FC(Cl)=C(Cl)C(F)(F)F</smiles>

the trans-1, 2-dichloro-3,3,3-trifluoropropene a chemical shift of $7.11 \mathrm{ppm}$ and $\mathrm{J}^{\mathrm{H}, \mathrm{F}}=1.1$ while for the cis isomer a $6.64 \mathrm{ppm}$ and $\mathrm{J}^{\mathrm{H}, \mathrm{F}}<0.2$. Since $\mathrm{Cl}$ and $\mathrm{SF}_{5}$ groups have a similar electronegativity the only difference between the 1,2 dichloro isomers and the $\mathrm{SF}_{5}$ isomers is that bromine is present in the latter. It is felt that this difference is unimportant in comparing the relative coupling constants between the $\mathrm{CF}_{3}$ and $\mathrm{H}$ groups in the 1,2 dichloro isomers and the $\mathrm{SF}_{5}$ isomers.

Since the $\mathrm{CF}_{3}-\mathrm{H}$ long range coupling in the first g.c. isomer is much larger than the second $\mathrm{g} \cdot \mathrm{c}$. isomer it is assigned by analogy to the trans-1, 2-dichloro-3,3,3-trifluoropropene the entegegen form:

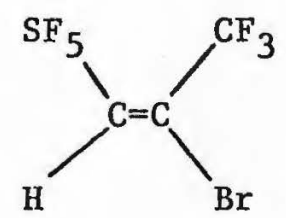

Entegegen isomer<smiles>[Z16]C(Cl)=CCl</smiles>

trans-

It is also important to note that the $\mathrm{CH}$ chemical shift is further downfield from TMS for both the entegegen isomer and the trans 1,2-dichloro-isomer relative to the zusammen and cis 1,2-dichloroisomer.

The second $g . c$. isomer is assigned as the zusammen isomer:<smiles>[13CH2]/C(Br)=C\[SbH2]</smiles>

Zusammen isomer<smiles>ClC(Cl)=C[123I]</smiles>

cis- 
The proton nmr spectrum for $\mathrm{SF}_{5} \mathrm{CH}=\mathrm{C}\left(\mathrm{CH}_{3}\right) \mathrm{Br}$ gives for the $\mathrm{CH}$ proton a five line pattern with a band center of $6.76 \mathrm{ppm}$ and a coupling constant $\mathrm{J}_{1,1}^{\mathrm{H}, \mathrm{F}}=7.8 \mathrm{cps}$. The basic $\mathrm{CH}$ five line pattern also shows additional long-range splitting by the $\mathrm{CH}_{3}$ protons. The coupling constant for this long range effect splits the $\mathrm{CH}_{3}$ protons into a five line spectra with a coupling constant of $1.5-2.0 \mathrm{cps}$. Integration of the areas for the $\mathrm{CH}$ peaks and for the $\mathrm{CH}_{3}$ peaks for $\mathrm{SF}_{5} \mathrm{CH}=\mathrm{C}\left(\mathrm{CH}_{3}\right) \mathrm{Br}$ gives a ratio of $1: 3$. The band center for the $\mathrm{CH}_{3}$ protons is $2.57 \mathrm{ppm}$ downfield from TMS. The overall nmr data for this compound is more similar to the nmr data for the second g.c. isomer of $\mathrm{SF}_{5} \mathrm{CH}=\mathrm{C}\left(\mathrm{CF}_{3}\right) \mathrm{Br}$. The proposed tentative structure for $\mathrm{SF}_{5} \mathrm{CH}=\mathrm{C}\left(\mathrm{CH}_{3}\right) \mathrm{Br}$, by analogy to the structure assignment for the zusammen isomer for $\mathrm{SF}_{5} \mathrm{CH}=\mathrm{C}\left(\mathrm{CF}_{3}\right) \mathrm{Br}$ is:<smiles>CC(Br)c1ccccc1</smiles>

\section{Discussion}

Previous work in our group has shown that when $\mathrm{SF}_{5} \mathrm{Br}$ adds to fluoroolefins the $\mathrm{SF}_{5}$ group is always attached to the carbon with the most hydrogens :

$$
\begin{aligned}
& \mathrm{SF}_{5} \mathrm{Br}+\mathrm{CF}_{2}=\mathrm{CFH} \longrightarrow \mathrm{SF}_{5} \mathrm{CFHCF}_{2} \mathrm{Br} \\
& \mathrm{SF}_{5} \mathrm{Br}+\mathrm{CF}_{2}=\mathrm{CH}_{2} \rightarrow \mathrm{SF}_{5} \mathrm{CH}_{2} \mathrm{CF}_{2} \mathrm{Br} \\
& \mathrm{SF}_{5} \mathrm{Br}+\mathrm{CFH}=\mathrm{CH}_{2} \rightarrow \mathrm{SF}_{5} \mathrm{CH}_{2} \mathrm{CFHBr}
\end{aligned}
$$


The work reported in this thesis for the addition of $\mathrm{SF}_{5} \mathrm{Br}$ to $\mathrm{CH}_{2}=\mathrm{CFC1}$ and $\mathrm{CF}_{2}=\mathrm{CClH}$ is interesting in that the first exception to the above rule is found with $\mathrm{CF}_{2}=\mathrm{CClH}$ but not for $\mathrm{CH}_{2}=\mathrm{CFCl}$ :

$$
\begin{aligned}
& \mathrm{SF}_{5} \mathrm{Br}+\mathrm{CH}_{2}=\mathrm{CFCl} \longrightarrow \mathrm{SF}_{5} \mathrm{CH}_{2} \mathrm{CFClBr} \\
& \mathrm{SF}_{5} \mathrm{Br}+\mathrm{CF}_{2}=\mathrm{CClH} \longrightarrow \mathrm{SF}_{5} \mathrm{CF}_{2} \mathrm{CC} 1 \mathrm{HBr}
\end{aligned}
$$

It is tempting to rationalize these results using steric effects (larger chlorine versus fluorine for $\mathrm{CF}_{2}=\mathrm{CFH}$ and $\mathrm{CF}_{2}=\mathrm{CClH}$ ) or using the stability of secondary radicals $\left(\mathrm{SF}_{5} \mathrm{CF}_{2} \mathrm{CClH}\right.$ vs. $\mathrm{SF}_{5} \mathrm{CClHCF}_{2}$.) but the author feels that additional model compounds (i.e. $\mathrm{CHCl}=\mathrm{CHF}$ ) must be examined before reaching any definite conclusions. The infrared spectra, mass spectra, and nmr spectra have adequately characterized the structure of these compounds.

In addition to the work dealing with fluoroolefins, the addition of $\mathrm{SF}_{5} \mathrm{Br}$ to alkynes $\left(\mathrm{CF}_{3} \mathrm{C} \equiv \mathrm{CH}\right.$ and $\left.\mathrm{CH}_{3} \mathrm{C} \equiv \mathrm{CH}\right)$ was studied. In both cases the $\mathrm{SF}_{5}$ group attached itself to the carbon with most hydrogens:

$$
\begin{aligned}
& \mathrm{SF}_{5} \mathrm{Br}+\mathrm{CH}_{3} \mathrm{C} \equiv \mathrm{CH} \Rightarrow \mathrm{SF}_{5} \mathrm{CH}=\mathrm{C}\left(\mathrm{CH}_{3}\right) \mathrm{Br} \\
& \mathrm{SF}_{5} \mathrm{Br}+\mathrm{CF}_{3} \mathrm{C} \equiv \mathrm{CH} \Rightarrow \mathrm{SF}_{5} \mathrm{CH}=\mathrm{C}\left(\mathrm{CF}_{3}\right) \mathrm{Br}
\end{aligned}
$$

With $\mathrm{CH}_{3} \mathrm{C}=\mathrm{CH}$ only one isomer was found and by analogy to the $\mathrm{SF}_{5} \mathrm{CH}=\mathrm{C}\left(\mathrm{CF}_{3}\right) \mathrm{Br}$ isomers is thought to have the following structure:<smiles>CC=C(C)Br</smiles>

It was extremely interesting to find that reaction product, $\mathrm{SF}_{5} \mathrm{CH}=\mathrm{C}\left(\mathrm{CF}_{3}\right) \mathrm{Br}$, was a mixture of two isomers with following structures: 


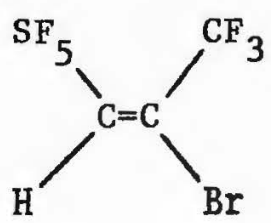

Entegegen (E) isomer

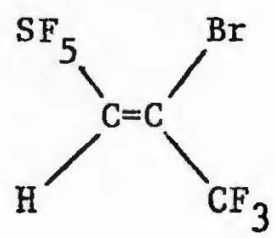

Zusammen ( $\mathrm{Z}$ ) isomer

The infrared and mass spectra of the $\mathrm{E}$ and $\mathrm{z}$ isomers are particularly interesting. The infrared, $\mathrm{C}=\mathrm{C}$ stretching frequency for the $\mathrm{E}$ isomer is $1637 \mathrm{~cm}^{-1}$ and for the $\mathrm{Z}$ isomer is $1630 \mathrm{~cm}^{-1}$. The shift to lower frequency for the $\mathrm{Z}$ isomer is probably best explained by a mass effect. Having the two heaviest groups $\left(\mathrm{SF}_{5}\right.$ and $\left.\mathrm{Br}\right)$ cis to each other creates more of a strain on the carbon-carbon double bond which can only be relieved by some distortion of that bond. This shift to lower frequency is a result of that distortion. This effect is also noted for other cis-trans olefins [(i.e. $\mathrm{CHBr}=\mathrm{CHF})]$. As already mentioned the $\mathrm{E}$ isomer (first $\mathrm{g} \cdot \mathrm{c}$. isomer) loses fluorine more readily than the $\mathrm{Z}$ isomer (second g.c. isomer). In attempting to explain this result the following sequence of events is visualized:

First the $\mathrm{E}$ isomer loses an electron, probably from bromine to create a primary positive radical:

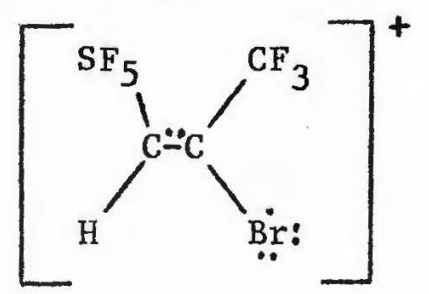


The lone electron on bromine and an electron from the double bond join to form a $\mathrm{C}=\mathrm{Br}$ bond:

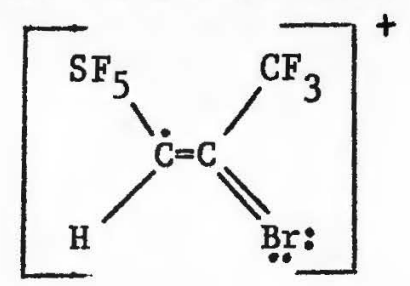

The next step involves a sulfur fluorine bond in which one of the electrons in a sulfur-fluorine bond joins with the lone electron on the secondary radical to form a $\mathrm{C}=\mathrm{S}$ bond and eliminate a fluorine free radical:

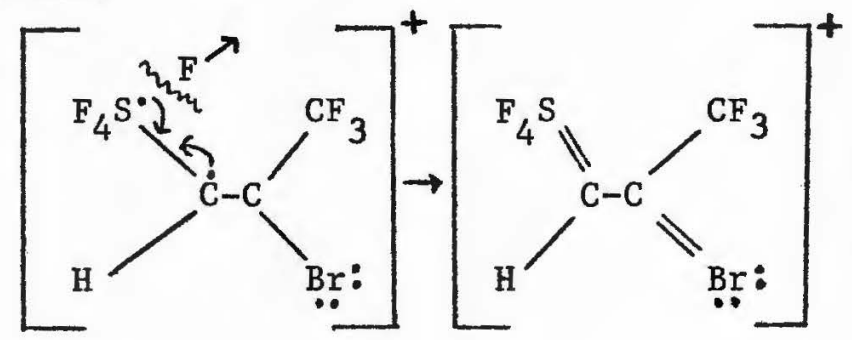

Since the $\mathrm{CF}_{3}$ group is larger than a bromine group* the repulsion between the $\mathrm{SF}_{5}-\mathrm{CF}_{3}$ groups in the cis position is reduced by the elimination of the fluorine atom. When the $\mathrm{SF}_{5}$ group is cis to bromine the repulsion is less and fluorine elimination is not as pronounced. The infrared and proton nmr spectra for the new compounds are shown in Figures II - XI.

*The covalent diameter as calculated from the observed interatomic distance in suitable covalent compounds is $3.3 \AA$ for a $\mathrm{CF}_{3}$ group, $2.8 \AA$ for a $\mathrm{CH}_{3}$ group and $2.3 \AA$ for a $\mathrm{Br}$ atom (34). 


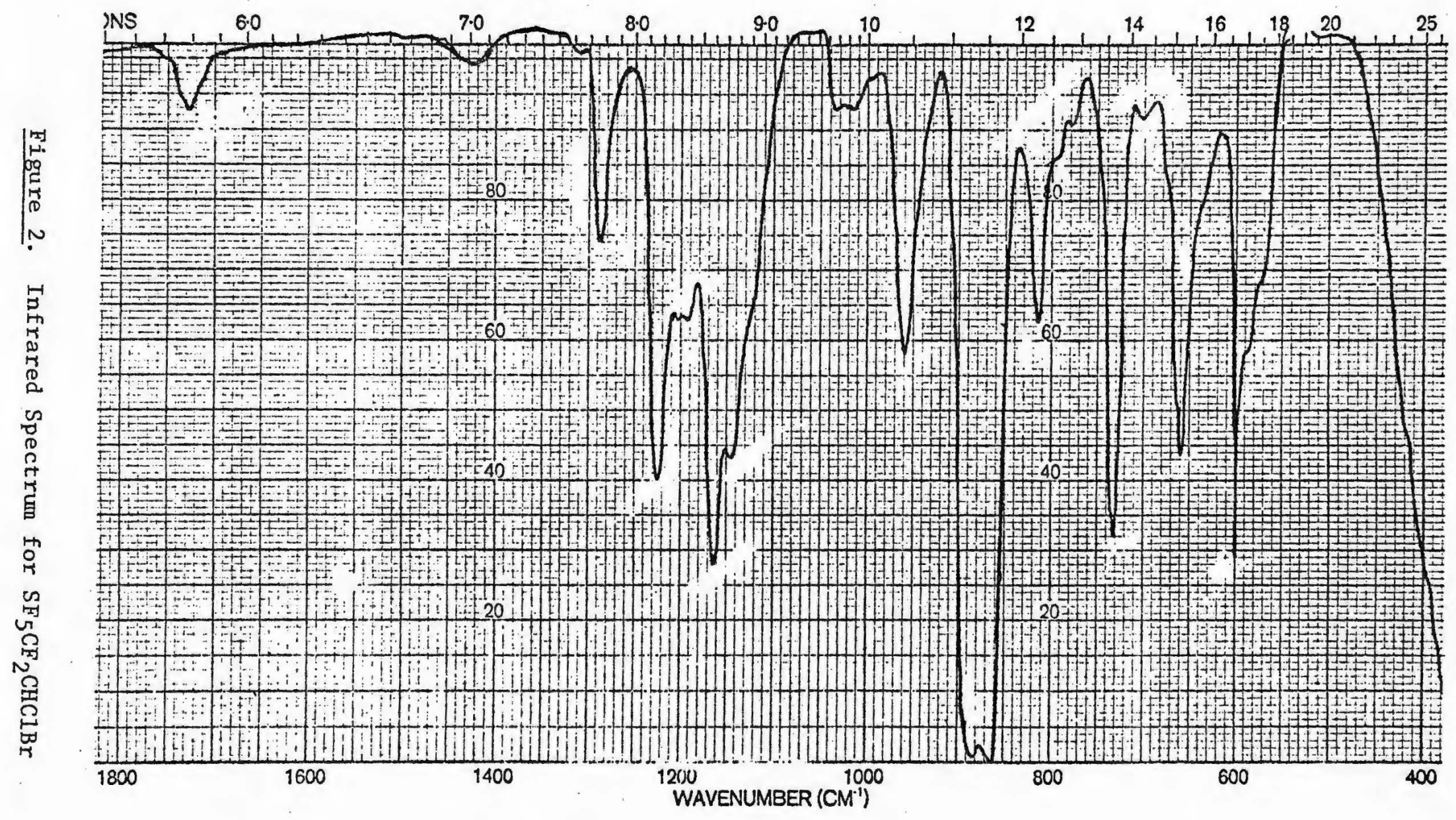


8.0

9.0

10

12

14

16

$18 \quad 20$

25

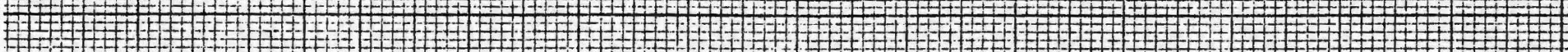

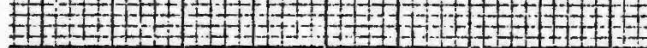

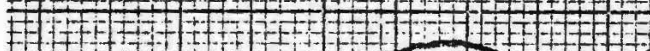

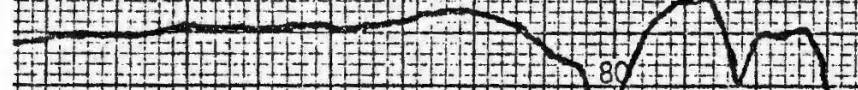

=

$+1+1+1$

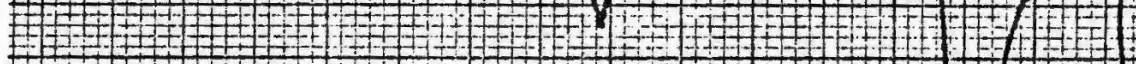

皇

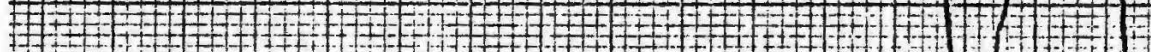

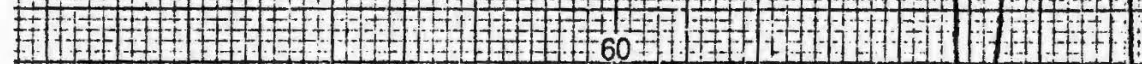

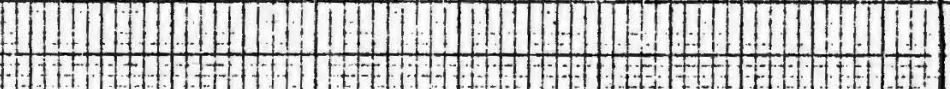

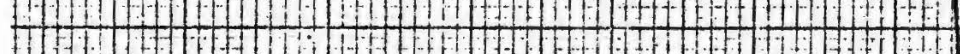

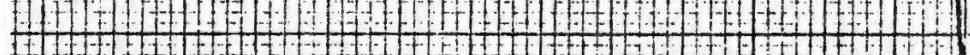

$+$

H+r

$(1+1)+1$

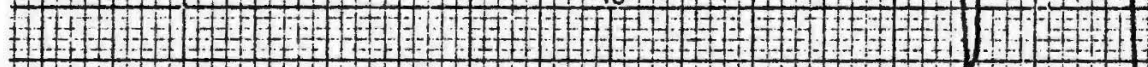

Q

植

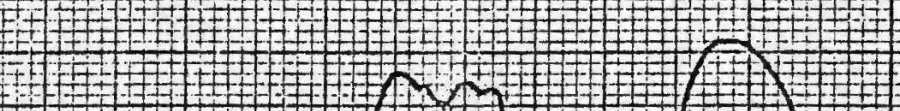

1)

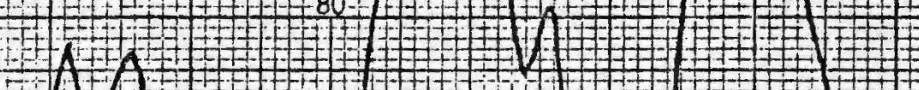

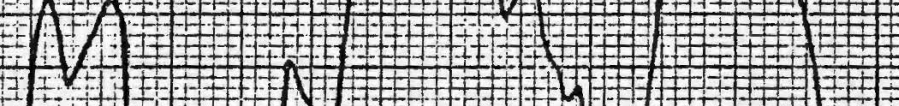

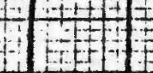

$\frac{7+2}{+1+12}$

$6 0 \longdiv { + 1 + 7 + 1 0 }$

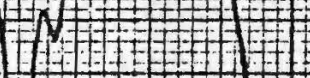

11.1

$1+2+1+1$

$1+1+2+1$

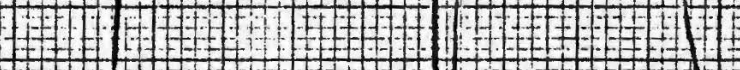

$+1+1$

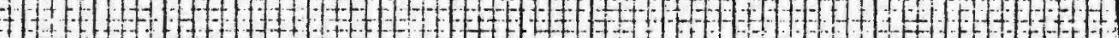

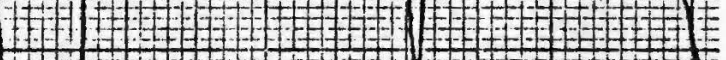

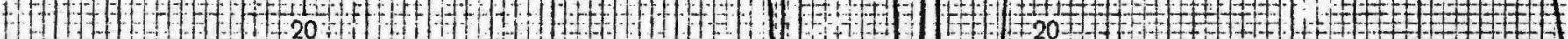

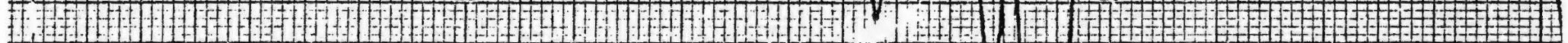
球

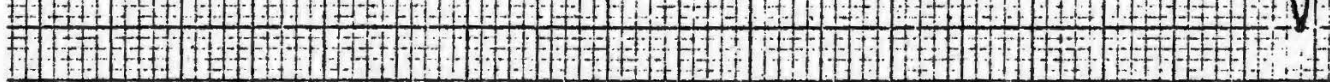

$\frac{5+200}{1800}$

1600

1400

1200

1000

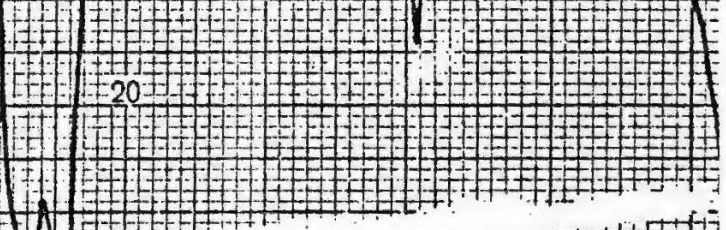

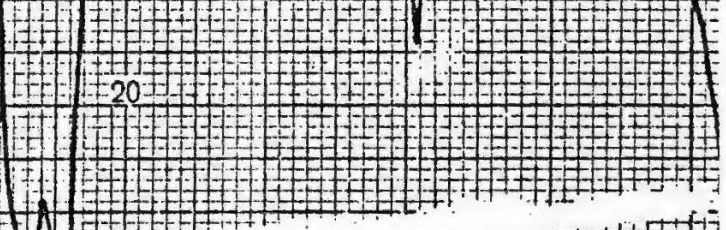
$\sqrt{1+2}=$

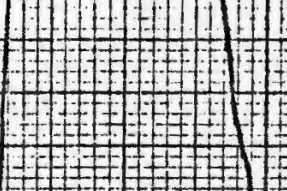
$1+1+2+2$

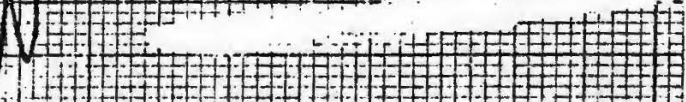
WAVENUMBER $\left(\mathrm{CM}^{-1}\right)$

800

600

400 


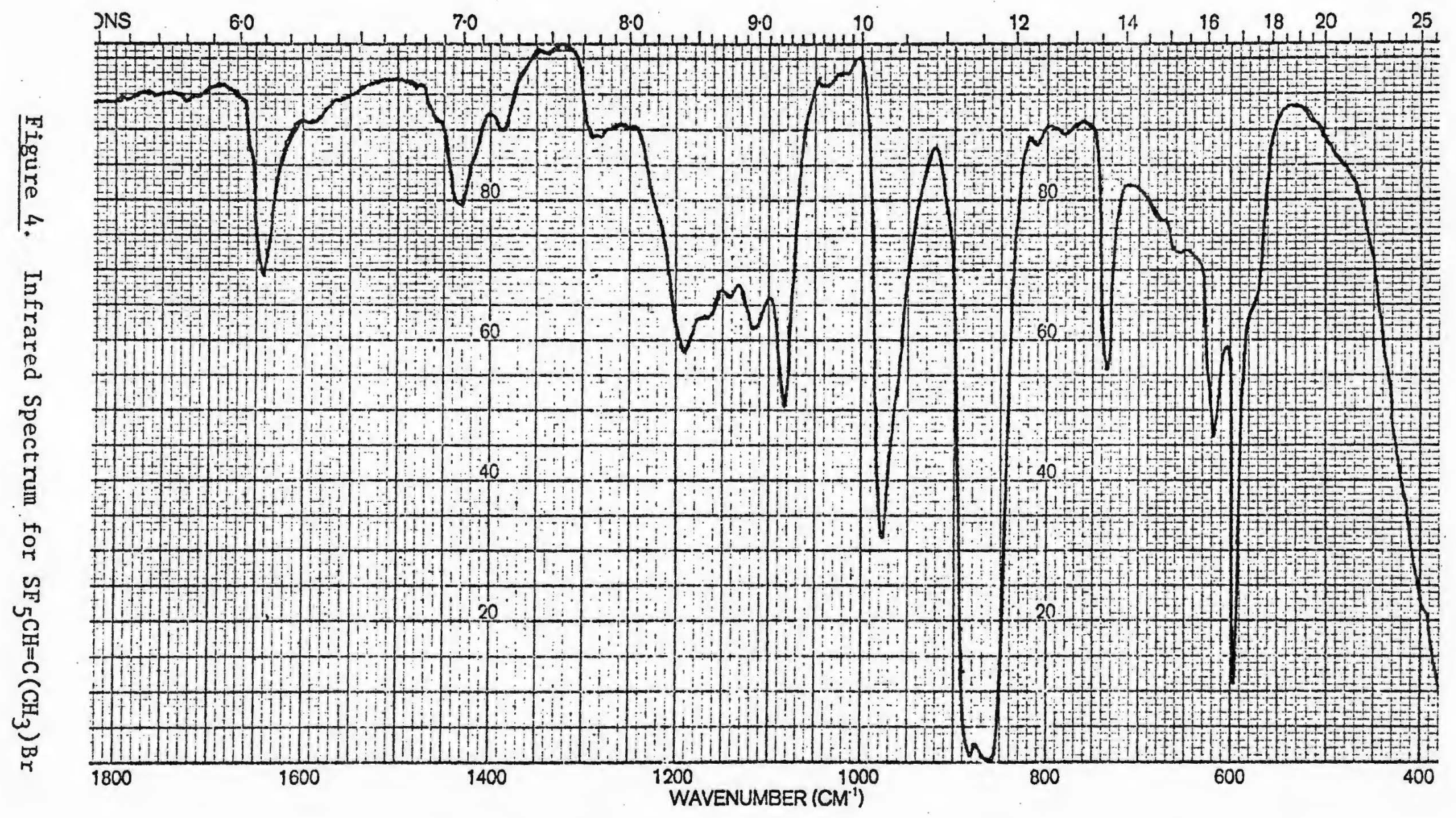


JNS

6.0

7.0

8.0

9.0

10

12

14

16

- 19 -

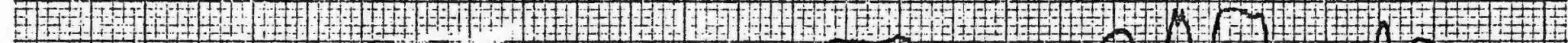

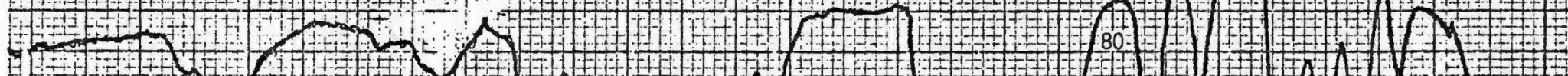

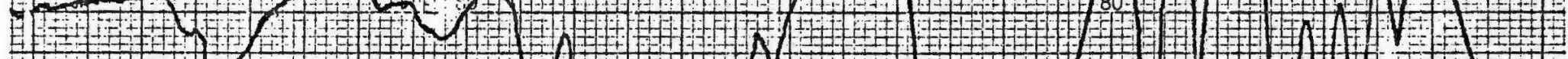

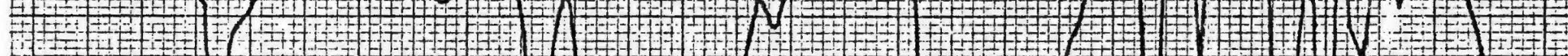

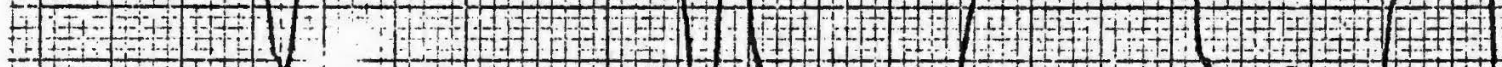

10 to

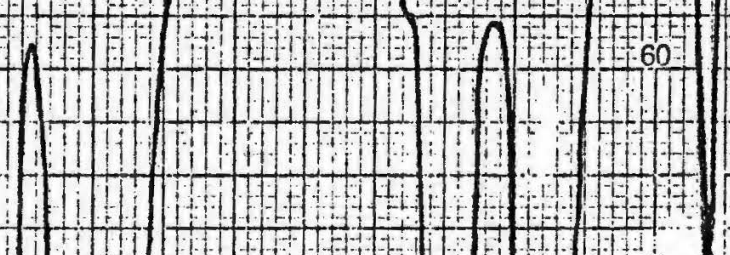
14

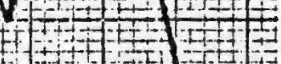

2 0
1 EHA 0 (n) 11

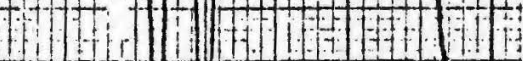
34 It

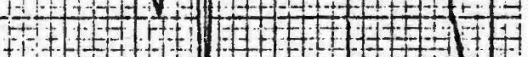

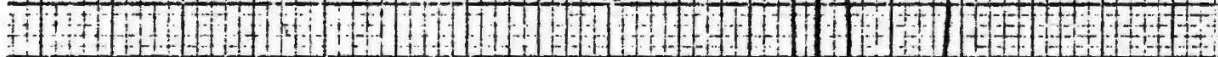

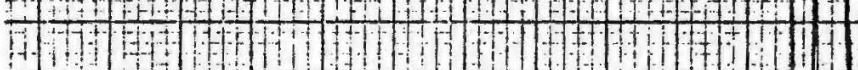

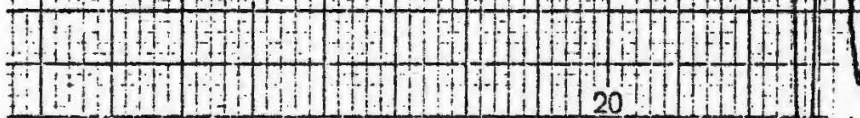
1.0.

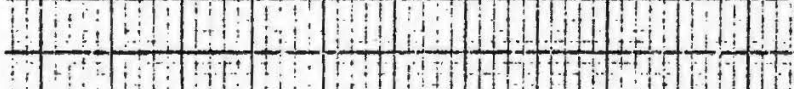
$+\frac{1}{1}$ $\frac{1}{1800} \frac{1000}{1600}$ $+1+210$

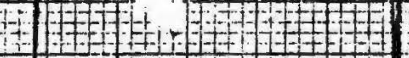

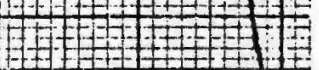

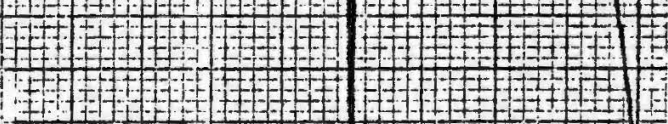

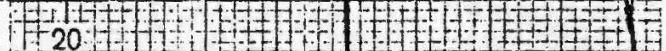
A.

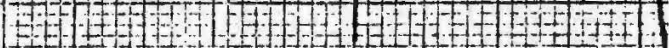

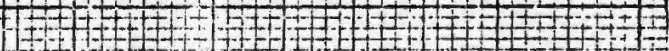
[1] 800 600 400 


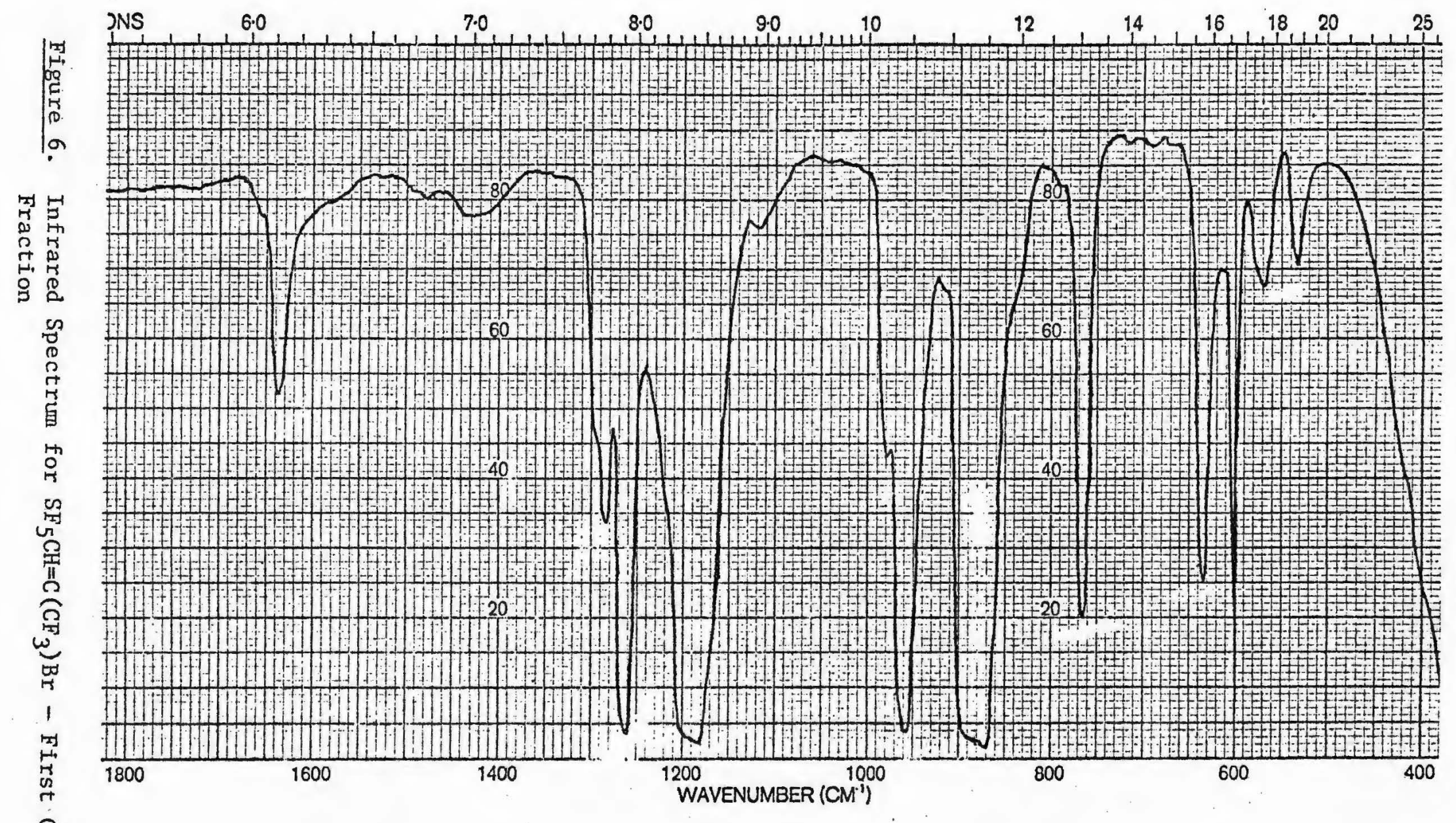




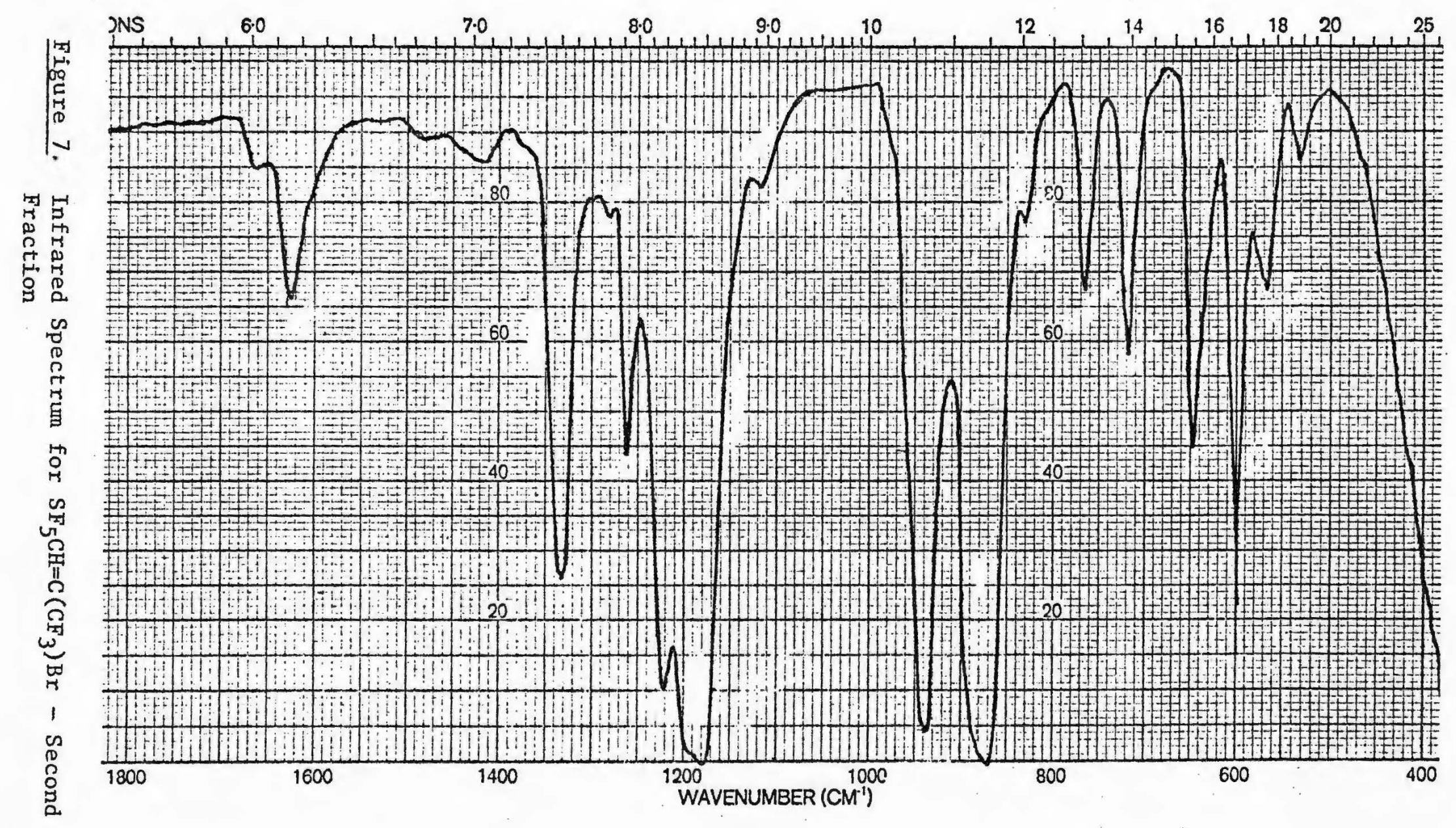




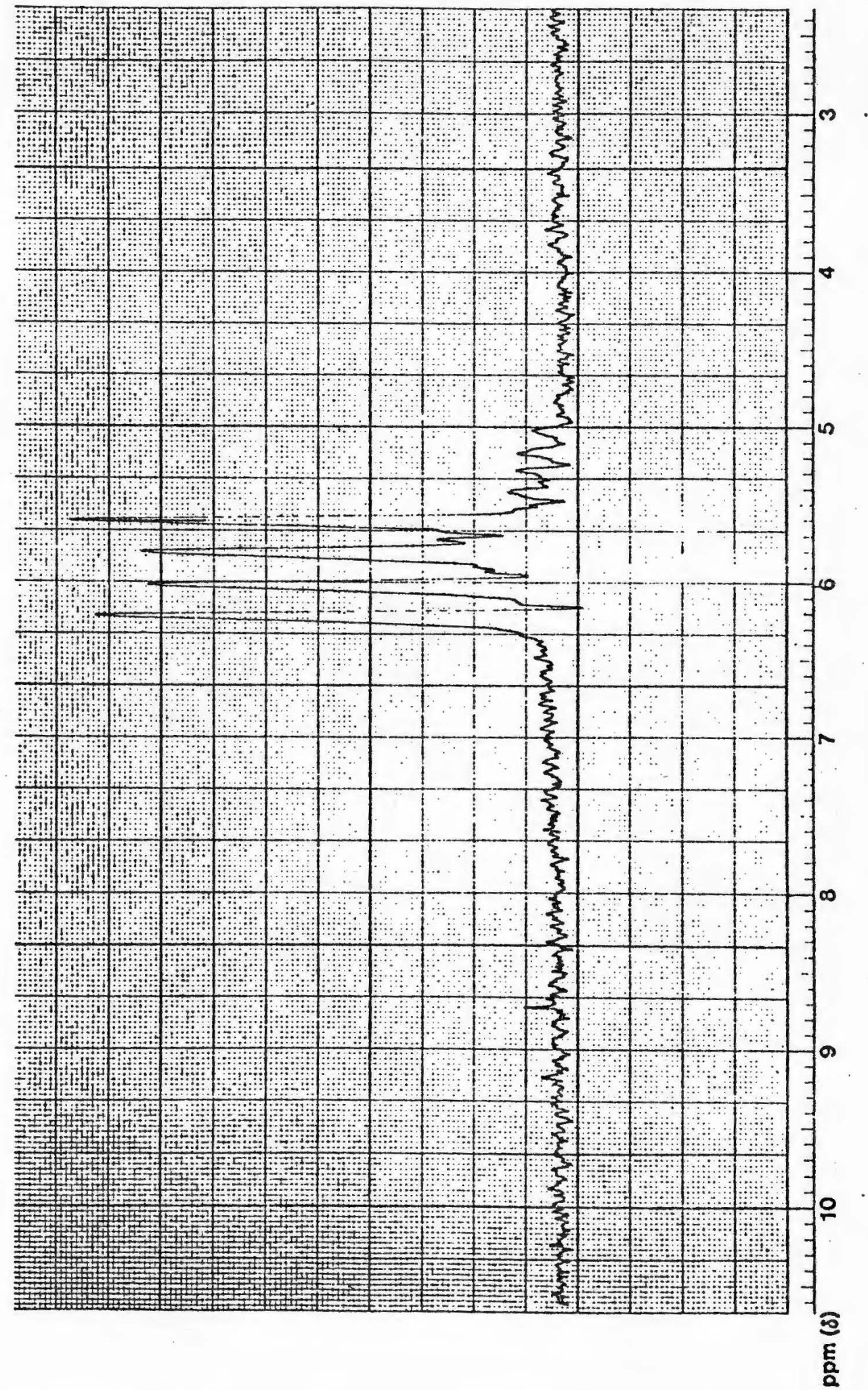

Figure 8. NMR Proton Spectrum for $\mathrm{SF}_{5} \mathrm{CF}_{2} \mathrm{CHClBr}$ 


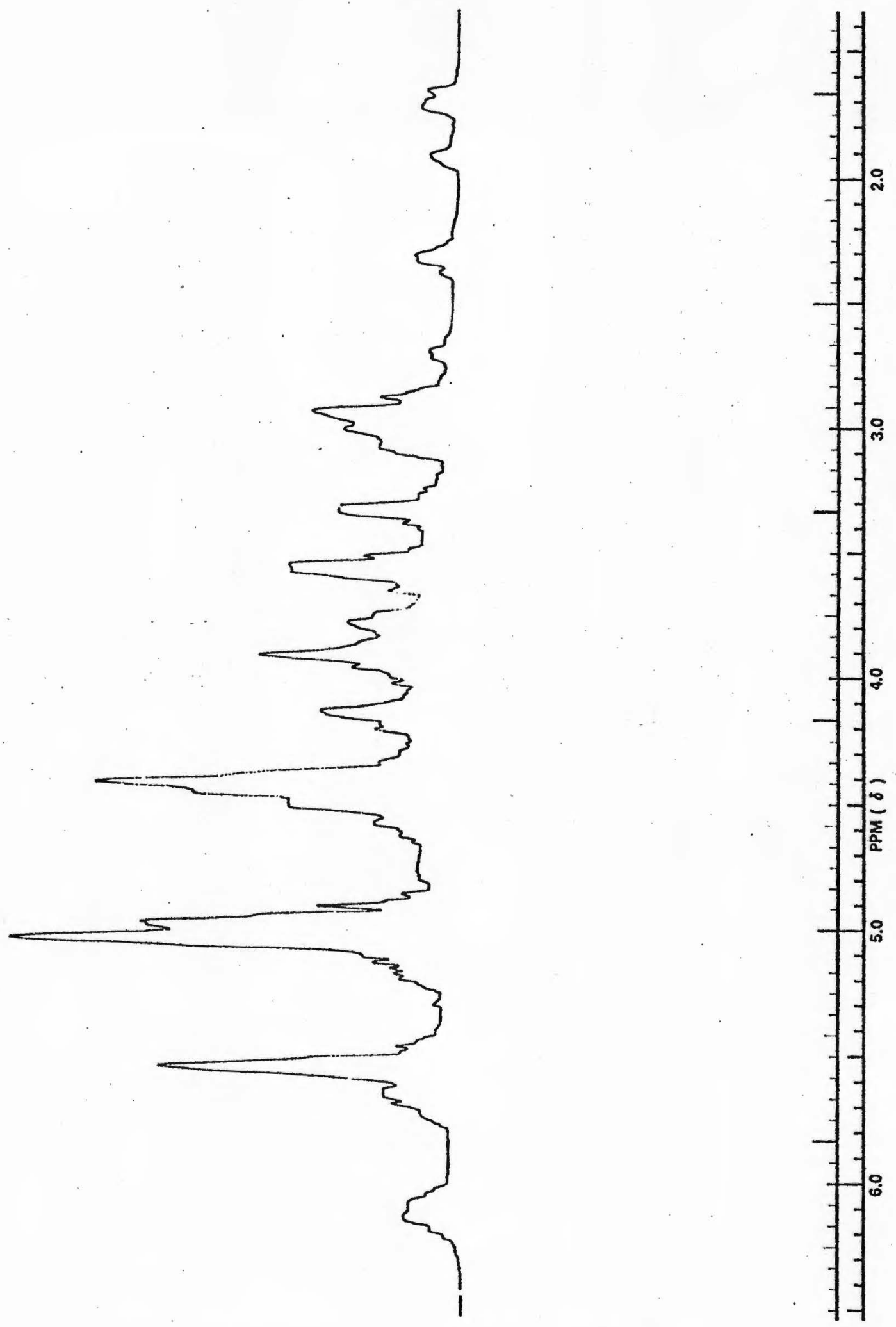

Figure 9. NMR Proton Spectrum for $\mathrm{SF}_{5} \mathrm{CH}_{2} \mathrm{CFBrCl}$ 
57

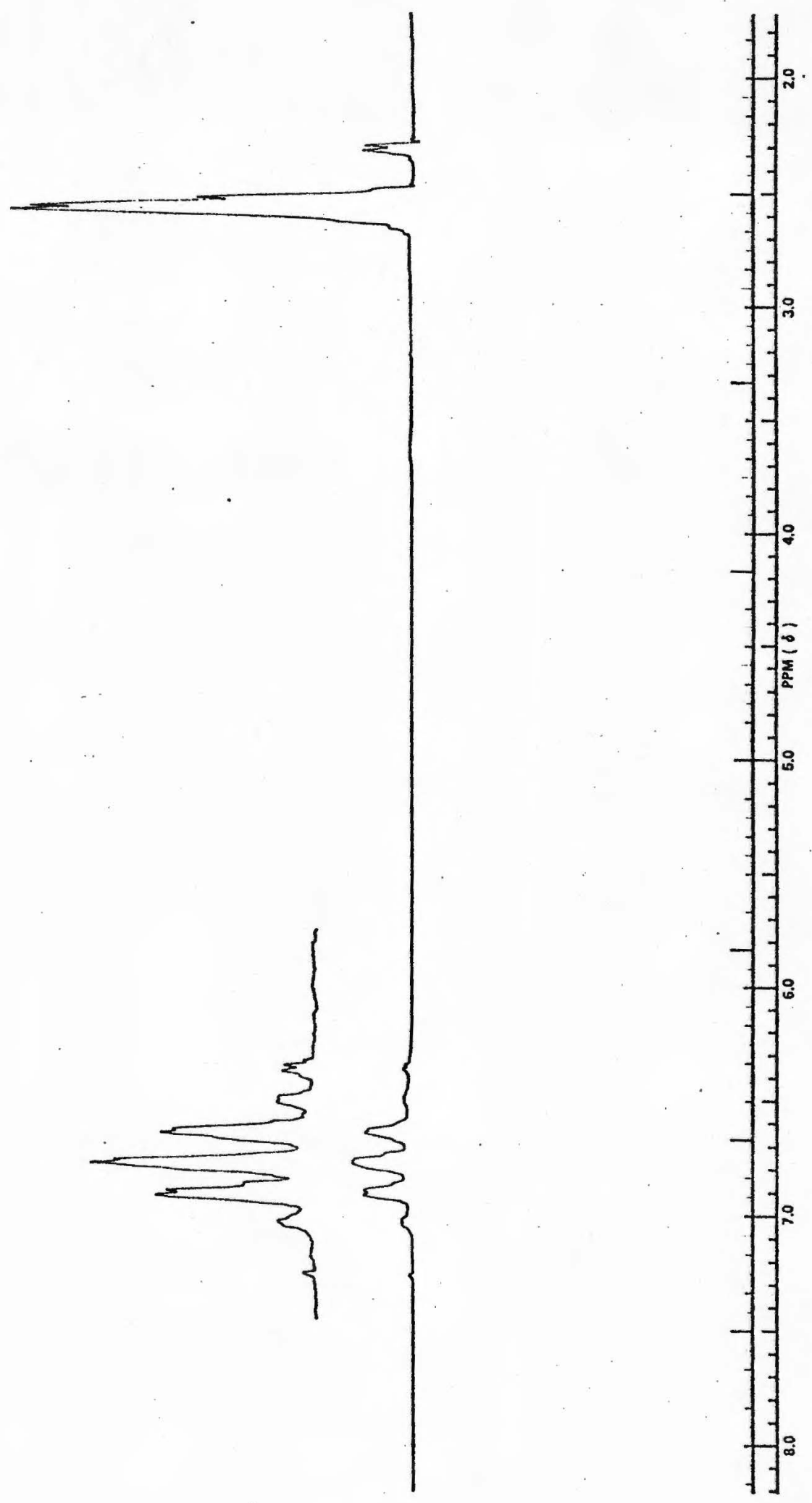

Figure 10. NMR Proton Spectrum for $\mathrm{SF}_{5} \mathrm{CH}=\mathrm{C}\left(\mathrm{CH}_{3}\right) \mathrm{Br}$ 
58
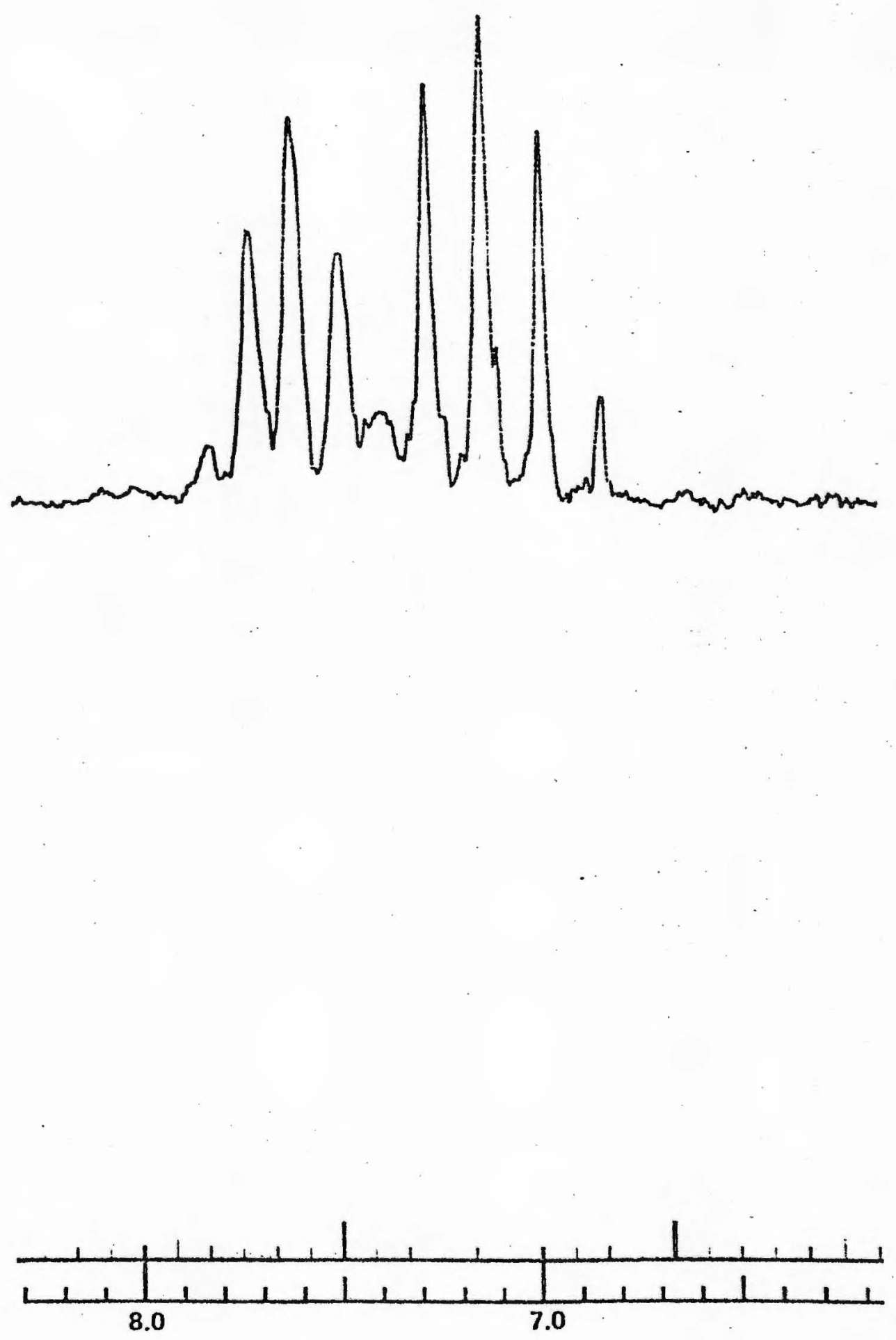

Figure 11. NMR Proton Spectrum for $\mathrm{SF}_{5} \mathrm{CH}=\mathrm{C}\left(\mathrm{CF}_{3}\right) \mathrm{Br}$ Mixture 


\section{BIBLIOGRAPHY}

1. C. Merrill, Ph.D. Thesis, University of Washington, Seattle, Wash. (1962).

2. B. Cohen and A. G. MacDiamid, Inorg. Chem., 4, 1782 (1965).

3. R. Kriohnanachari and N. Mohan, Acta. Phys., 36, 915 (1969).

4. J. Stewart, L. Kegly, H. F. White and G. L. Gard, J. Org. Chem., 34, 760 (1969).

5. A. D. Berry and W. B. Fox, J. Fluorine Chem., 6, 175 (1975).

6. A. D. Berry and W. B. Fox, J. Fluorine Chem, to be published.

7. H. L. Roberts and N. H. Ray, J. Chem. Soc., 136, 665 (1960).

8. H. L. Roberts, et al., J. Chem. Soc., 2066 (1961).

9. H. L. Roberts, et a1., J. Chem. Soc., 2070 (1961).

10. Canadian Patent, No. 728186 (1966).

11. R. A. Bekhen, B. L. Gyatkin, and I. L. Knunyants, I. Z. V. Akad. Nauk. SSSR, 2738 (1970).

12. F. W. Hoover and D. D. Coffman, J. Org. Chem., 29, 3567 (1964).

13. G. L. Gard and C. Woolf, J. Fluorine Chem., 1, 487 (1971/72).

14. S. Sherratt, British Patent, No. 929990 (1963).

15. A. Marcellis and R. E. Eibeck, J. Fluorine Chem., 5, 71 (1975).

16. H. I. Roberts, Quart. Rev., 15, 30 (1961).

17. W. A. Sheppard, J. Amer. Chem. Soc., 84, 3072 (1962).

18. K. C. Denbigh and R. Whytlaw-Gray, J. Chem. Soc., 1346, (1964).

19. W. R. Trost and R. L. McIntosh, Can. J. Chem., 29, 508 (1951).

20. H. L. Roberts, J. Chem. Soc., 3183 (1962).

21. M. Tremblay, Can. J. Chem., 43, 219 (1965). 
22. J. Hutchinson, J. Fluorine Chem., 3, 429 (1973).

23. J. C. Walton, et a1., Trans. Faraday Soc., 65, 2103 (1959).

24. J. C. Walton, et al., Trans. Faraday Soc., 66, 2039 (1970).

25. G. H. Cady, "Fluorine Containing Compounds of Sulfur," Advances in Inorganic Chemistry and Radiochemistry, Vol. 2 (1960).

26. G. L. Gard, C. Woolf and R. Shaw, British Patent, No. 1, 167, 228 (1969).

27. C. Woolf and G. L. Gard, United States Patent, No. 3,448,121 (1969).

28. E. E. Gilbert and G. L. Gard, United States Patent No. 3,475,453 (1969).

29. R. D. Dresdner, T. J. Kao and J. A. Young, J. Am. Chem. Soc., 80, 3007 (1958).

30. L. H. Cross, G. Cushing and H. L. Roberts, Spectrochim. Acta., 17, 364 (1961).

31. J. K. Brown and K. J. Morgan, "The Vibrational Spectra of Organic Fluorine Compounds," Advances in Fluorine Chemistry, Vol. 4 (1965).

32. L. J. Bellamy, "The Infra-Red Spectra of Complex Molecules," Methuen, London (1958).

33. W. G. Finnegan and W. P. Norris, J. Org. Chem., 28, 1139 (1963).

34. H. P. Braendlin and E. T. McBee, "Effects of Adjacent Perfluoroalkyl Groups on Carbonyl Reactivity Advances in Fluorine Chemistry, Vo1. 3 (1963). 